This item was submitted to Loughborough's Research Repository by the author.

Items in Figshare are protected by copyright, with all rights reserved, unless otherwise indicated.

\title{
Determinants of CSR disclosure in Mexico
}

PLEASE CITE THE PUBLISHED VERSION

https://doi.org/10.1504/IJBAAF.2020.107943

PUBLISHER

Inderscience

VERSION

AM (Accepted Manuscript)

PUBLISHER STATEMENT

This paper was accepted for publication in the journal International Journal of Banking, Accounting and Finance and the definitive published version is available at doi.org/10.1504/IJBAAF.2020.107943

\section{LICENCE}

CC BY-NC-ND 4.0

\section{REPOSITORY RECORD}

Arena, Claudia, Yanira Petrides, and Petros Vourvachis. 2020. "Determinants of CSR Disclosure in Mexico". Loughborough University. https://hdl.handle.net/2134/35134. 


\title{
Determinants of CSR disclosure in Mexico
}

\begin{abstract}
This paper investigates Corporate Social (and environmental) Responsibility (CSR) disclosure practices in Mexico. By analysing a sample of Mexican companies in 2010, it utilises a detailed manual content analysis and identifies corporate-governance-related determinants of CSR disclosure. The study shows a general association between the governance variables and both the content and the semantic properties of CSR information published by Mexican companies. Although an increased international influence on CSR disclosure is noted, the study reveals the symbolic role of CSR committees and the negative influence of foreign ownership on community disclosure, suggesting that improvements in business engagement with stakeholders are needed for CSR to be instrumental in business conduct.
\end{abstract}

Keywords: Corporate Social Responsibility (CSR); CSR disclosure; disclosure determinants; Mexico; corporate governance; legitimacy theory; stakeholder engagement; content analysis

\section{Introduction}

This paper's aim is to offer a comprehensive examination of Corporate Social (and environmental) Responsibility (CSR) reporting practices in Mexico. The country presents a worthwhile field of CSR research due to its size, geographic position, and major social and environmental challenges faced. Mexico is among the largest countries in the world (currently ranked fourteenth in terms of total area and eleventh in terms of population and Gross Domestic Product (GDP) (US Department of State, 2016) and is the second most populated in Latin America. At the same time, most of the country's exports are supplied to the United States. Indeed, Mexico's proximity to the US constitutes a major economic asset and is perceived to be influencing Mexican corporations' (as well as regulators) disclosure policies (Husted and Serrano, 2002).

Whilst Mexico is expected to be the world's fifth largest economy by 2050 (TheCatalist, 2010), social inequality currently prevails, extremes of wealth and poverty co-exist, and economic development tends to benefit the already privileged (Paul et al., 2006). The Mexican National Council for the Evaluation of Social Development Policy reports that in 2010 an estimated 52 million (approximately 46\% of the population) lived in poverty. Particularly Mexico's indigenous population, the largest in Latin America, is significantly disadvantaged in both economic and social outcomes (The World Bank, 2012). The country also faces considerable environmental challenges, with its rich biodiversity being threatened: at present, it is second in the world in ecosystems and fourth in overall species but it also shows fast rates of deforestation (currently fifteenth in the world, whilst in 2002 was as high as second (BBC News, 2002; Global Forest Watch, 2016).

Research into Mexican companies' CSR reporting practices however remains scant and rather inconclusive. The extant literature mostly draws conclusions from rather descriptive accounts employing rudimentary content analysis under either case studies or survey designs (see, e.g., Logsdon et al., 2006; Meyskens and Paul, 2010; Paul et al., 


\section{Authors}

2006). Although there appears to be clear evidence of on-going increases in CSR reporting adoption trends, it is less clear how organisations use their available reporting media and what the drivers of the increased disclosures are. Interestingly, the literature also agrees that common 'external' drivers found in other settings, such as regulation or stakeholder engagement, do not appear to be at work in Mexico (Velásquez et al., 2009; Weyzig, 2006), thus highlighting the need for further research and for adopting more sophisticated designs and alternative theoretical propositions.

An important, albeit unanswered, question is whether, and to what extent, internal corporate governance characteristics affect the reporting behaviours of Mexican firms. Exploring the role of corporate governance for CSR disclosure in Mexican firms is particularly worthwhile, given the lack of stakeholder engagement and related regulation in this country, which suggest the presence of potential internal drivers. In line with other Latin American countries, Mexico indeed has an insider, family-owned governance system that is characterised by concentrated equity ownership, a weak emphasis on minority interest protection in securities law and regulation, and relatively weak requirements for disclosure (Husted and Serrano, 2002). Concern about corporate governance has been increasing in Mexico, principally due to the demands of international investors and the pressures faced by newly privatised companies as well as the process of mimetic isomorphism within Mexico, where business people are responding to governance movements in other countries, particularly its neighbour, the USA. However, a major threat to its corporate governance model arises from the conflicts occurring among families that desire to retain control in the face of increased needs for external financing (Orantes, 2016).

In such context, the role of the governance mechanisms in ensuring firm transparency is pivotal. Despite the recent improvements in the corporate governance induced by securities laws and best corporate practices codes, the effectiveness of governance mechanisms is still undermined by strong family control, shared directorships across companies, a weak legal environment based on the civil law tradition and limited law enforcement mechanisms (Machuga and Teitel, 2009).

In an attempt to explore these arguments, we examine the extent to which several corporate governance characteristics related to the ownership structure and the composition of firm governing bodies affect CSR reporting behaviour. We specifically focus on foreign ownership, board composition (proportion of independent directors), board leadership (whether CEO is also the chairperson of the board), gender diversity (proportion of female directors) and structure (whether there is a CSR dedicated committee), as prior literature (Khan et al., 2013; Kolk and Pinkse, 2010; Michelon and Parbonetti, 2012) suggests they are among the most important internal drivers of CSR disclosure. Utilising a manual content analysis of an unprecedented (to this stream of CSR research) measurement detail, we conduct a survey of CSR reporting practices across sectors and reporting media. Then, we delve deeper into these findings by identifying and exploring a wide range of determinants of CSR disclosure. We specifically explore the association between governance mechanisms and semantic properties of CSR disclosure, including the economic sign (whether it is positive, negative or neutral) and accuracy (whether it is of monetary, numerical, declarative or pictorial nature). Our evidence suggests that legitimacy based drivers of CSR disclosure are also at play in Mexico. We find that corporate governance affects both the content and the semantic properties of CSR disclosure published as well as the choice of the 


\section{Determinants of CSR disclosure in Mexico}

disclosure medium and develop explanations for the noted differences in disclosure patterns.

The paper contributes to the literature in several ways. First, our paper adds to existing studies on corporate governance and CSR disclosure (Cerbioni and Parbonetti, 2007; Haniffa and Cooke, 2005; Michelon and Parbonetti, 2012) by providing an integration of accountability, stakeholder and legitimacy theories to assess the relationship between ownership structure and characteristics of the governing bodies to CSR disclosure. In doing so, we echo calls in the governance literature for wider accountability and in the CSR literature for governance at the company level (Bebbington, 2004; Brennan and Solomon, 2008). We argue that good corporate governance and CSR disclosure can be seen as complementary mechanisms used by companies to enhance relations with stakeholders and mediate potential conflicts with shareholders.

Second, by exploring governance-based determinants in a Latin American setting, we also contribute to the related growing literature in developing countries (Amezaga et al., 2013; Fifka, 2012; Muttakin and Subramaniam, 2015; Visser, 2008). The literature is rather inconclusive and generally focuses on commonly found external determinants. Focusing on the family-based Mexican setting, also given its proximity to the USA, offers further insights into the reasons behind these inconclusive findings. Moreover, in contrast to the previous studies, we go beyond the examination of the amount of disclosure to provide a comprehensive analysis of the content and the sematic features of the CSR disclosure of Mexican companies across different reporting media.

The remainder of the paper is structured as follows. The next section provides a background discussion on the institutional setting, which is followed by sections on the literature review, theoretical framework and hypotheses. The methods employed in the study are then presented, followed by the results and the concluding section, discussing key findings.

\section{Institutional setting}

CSR in Mexican firms seems to have distinct attributes that arise from Mexico's history, culture and values (Logsdon et al., 2006). The modern history of Mexico begins with the colonisation of the indigenous people living there (Aztecs and Maya) by Spanish explorers in the early 1500s. Subsequently, the Catholic Church played a very prominent role until the mid-1800s as the majority landowner in the country, generating income to finance schools, hospitals and social programmes (Arango, 2002). Tension about the power and wealth of the Catholic Church led to the nationalisation of its holdings in the 1860s and an increasing role of the state in meeting social needs. Nevertheless, the Catholic Church appears to continue to play an influential role in Mexican society and among a number of business leaders.

Throughout the $20^{\text {th }}$ century, the state had a powerful influence on the Mexican economy, with one political party, the PRI (the Institutional Revolutionary Party) dominating all branches of government from the 1930s to 2001. Much of this political history has been rooted in corruption, as has been the case in much of Latin America, which led to a weakened and illegitimate State, particularly with regard to the government regulation of business (Logsdon et al., 2006). The weakened State has also 


\section{Authors}

undermined the rule of law and has made room for informal rules and practices such as fidelity or family leadership to prevail and mediate accountability relationships. These practices remain acceptable and compatible to date by large Mexican companies, when they fulfil or adopt international standards and balance the interests of shareholders and stakeholders (Orantes, 2016). On-going corruption has also undermined the development of an alliance culture in Mexico, as different segments of society are used to operating independently instead of cooperating. This has, in turn, contributed to the generally noted lack of stakeholder engagement in CSR development, as this is predicated on trust, cultural affinity and recognition of each other's legitimacy. Instead, local stakeholder pressures have largely been lacking or are ineffective (Weyzig, 2006).

Since the 1980s, private corporations have become more instrumental in developing economic and social activities because of the deregulation in many industries and increased inward and outward trade and investment (Logsdon et al., 2006). Mexico now manufactures and exports more goods than any other Latin American country. In fact, foreign trade represents a larger percentage of Mexico's economy than it does for any other large country. Mexico's trade with the US and Canada has tripled since the implementation of the North American Free Trade Agreement (NAFTA) in 1994 (The Economist, 2012). The Mexican corporate sector has long been dominated by familyowned, highly diversified conglomerates organised as grupos, which have become increasingly important to the allocation of resources in the Mexican economy as a result of privatisation. In these groups, practices such as conflict of interest and lack of transparency in corporate governance appear to be quite common, despite these being unethical if not illegal in western settings (Logsdon et al., 2006). It is the competition for information in order to gain a market advantage that seems to have primarily caused "the majority of companies in Mexico [to] behave like black boxes” (Orantes, 2016, p.147).

In an attempt to improve accountability and information flows from corporations to their constituents, a Corporate Governance code was introduced in 1999. This was originally developed on a voluntary basis, although from 2003, listed companies have been required to indicate their degree of compliance. The Code was greatly influenced by the UK's corporate governance developments, was further facilitated by related guidelines in the NAFTA Agreement and came as a response to the Mexican banking crises in the 1990s (Orantes, 2016). It has been particularly explored whether rules practised by medium and large sized firms in the US and the international arena could be adopted in the Mexican setting. Related provisions highlighted the importance of hiring independent directors and the strategic function of the board and encouraged companies to disclose their degree of adherence to such practices in their annual reports (Husted and Serrano, 2002). Although this change in regulation was expected to trigger a wider cultural change to corporate practices, at present companies following corporate governance principles "are counted in hundreds, a number that is not representative of a market in which thousands of enterprises from different fields participate" (Orantes, 2016, p.149). The effectiveness of the Code is still undermined by the strong family control, shared directorships across companies, weak legal environment based on the civil law tradition and limited law enforcement mechanisms (Machuga and Teitel, 2009).

Although no formal requirements for CSR reporting appear to exist in Mexico, in 2004, the first standard by the Instituto Mexicano de Normalización y Certificación (IMNC) was published, titled "NMX - SAST - 004- IMNC 2004: Guidelines for the Implementation of a Management System of Social Responsibility" on 1 March 2005. The Mexican Standard for Social Responsibility became a benchmark for the 


\section{Determinants of CSR disclosure in Mexico}

development of ISO26000 on Social Responsibility. In 2012, Mexico was the first country in the developing world to pass a comprehensive climate change bill, with a goal for the country to generate 35\% of its energy from clean energy sources by 2024 and to cut emissions by 50\% by 2050, from the level found in 2000 (BBC News, 2012). Whether these developments reflect international trends or are shaped by the local context is a matter of considerable debate as discussed next.

\section{Literature review}

While the past decade has seen a dramatic growth in CSR disclosure (Cho et al., 2012), there appears to be a debate about whether CSR is largely a Western phenomenon (Chapple and Moon, 2005). Although earlier studies find firms operating in emerging and less developed countries lagging behind Western firms in many aspects of CSR (Baughn et al., 2007), more recent studies find CSR reporting to also be on the rise in emerging and less developed countries, in terms of both the number of companies publishing CSR information (KPMG, 2016; Plugge, 2008) and related research coverage (Fifka, 2012). A recent survey by KPMG indeed reports that over recent years CSR reporting practices have grown considerably both in terms of extent and quality in settings such as India, South East Asia and Africa, with European firms no longer leading the field (KPMG, 2016).

Studies examining the motivations and determinants of CSR disclosure across different settings report considerable variations in the depth, breadth and emphasis of disclosure (Baughn et al., 2007). Those focusing on CSR disclosures in less developed contexts highlight the controversial role of related business engagement, with organisations, e.g., often being praised for alleviating poverty (when seen as the means of economic development) and being accused for causing it (when viewed as profiteering at the expense of their local operating environments) (Blowfield and Murray, 2011). It seems to be the "structural dependences... of the less developed countries on foreign aid and foreign direct investments... coupled with cheap labour, large markets... and rich natural resources [which] make them susceptible to exploitation” (Belal et al., 2013, p.89). As the socio-economic realities of these countries are different, the corporate motivations for undertaking CSR reporting are also different, with "outside forces" often driving the agenda, such as international market pressures on export oriented economies (ibid.). Matten and Moon (2008) suggest that national differences in CSR can be explained by historically grown institutional frameworks that shape national business systems. Differences are attributed to political, financial, education/labour and cultural systems and to factors pertaining to the nature of the firm and to market processes and corporate control. Organisations operating in emerging and less developed countries, for example, appear to proportionately offer more positive disclosures than negative compared to their developed counterparts, reflecting the cultural settings as well as potentially the earlier stage of the development of the phenomenon (Chapple and Moon, 2005). Organisations in such countries also tend to prioritise social (i.e., employee and community) disclosure as opposed to legal, ethical or environmental disclosure (Belal et al., 2013; Visser, 2008). Visser (2008) particularly attributes the higher emphasis on philanthropy to the developing countries' reliance on aid and the nature of educational, health and social issues that are present. 


\section{Authors}

Characteristics related to the nature of the firm appear to be the ones most often explored, with a notable congruence observed across emerging and more developed settings. Economic aspects such as financial performance (whether this is measured as, e.g., share price returns or profitability or revenue) and variables related to industry all appear to be important factors mediating accountability relationships and related disclosure provisions, as further discussed in the methodology section (see, e.g., Araya, 2006; Baughn et al., 2007; Fifka, 2012). Furthermore, characteristics related to political interpretations, such as size, environmental/social performance and media exposure/public pressure are all typically applicable across settings (Baughn et al., 2007; Fifka, 2012). A number of studies also suggest that (e.g., Baylis et al., 1998; Gray et al., 1995) and provide supporting evidence for (e.g., Patten, 2000; Weber, 2014) regulation compliance as motivating factor for CSR reporting. Regulatory initiatives, however, seem to have had a varying degree of success, with a number of studies also reporting poor compliance and limited impact on disclosure (e.g., Day and Woodward, 2004; Fallan and Fallan, 2009; Larrinaga et al., 2002; Luque-Vílchez and Larrinaga, 2016). In contrast, Bebbington et al. (2012) report higher compliance with introduced informal CSR requirements in their UK sample, suggesting it could be easier for the latter to become accepted and standardised. To date, the provisions of CSR disclosures remain largely voluntary, with some notable exceptions around the world (such as China, Denmark, France, Indonesia, Italy, Malaysia, Norway, South Africa and Spain) but with none noted in Latin America (KPMG, 2016).

This largely unregulated environment allows discretion for companies to compete on the ethicality of their actions and communications. Corporate governance can, therefore, play an important role in shaping CSR systems: CSR needs governing at the company level, whilst corporate governance should also be informed by social responsibilities and be compatible to CSR (Matten and Moon, 2008; Moon, 2014). In less developed countries, CSR is often seen as a way to plug the 'governance gaps' left by weak, corrupt, or under-resourced governments that fail to adequately provide various social services (Visser, 2008). Matten and Moon (2008) see this as a part of a wider trend with weak institutions and poor governance, in which responsibility is often delegated to private actors. Improving corporate governance in these settings should, therefore, be assigned the highest CSR priority, as this potentially "holds the key to improvements in all the other dimensions, including economic development, rule of law, and voluntary action" (Visser, 2008, p.492). At present, it is often the case, as Belal et al. (2013) note, that when parent companies control subsidiaries operating in less developed economics, they often drive the latter's CSR agendas and disclosures. A growing number of studies has attempted to explore the link of corporate governance with CSR reporting and has so far produced conflicting results. Interestingly, literature on emerging and less developed countries, such as India (Muttakin and Subramaniam, 2015) and Malaysia (Haniffa and Cooke, 2005), seems to find stronger associations among CSR disclosure and governance variables compared to studies looking at more developed settings, such as Hong Kong (Gul and Leung, 2004) and Italy (Michelon and Parbonetti, 2012). The particulars of these studies are discussed in greater detail in the hypothesis section. It should be noted that to date there is no previous study attempting to explore corporate governance implications on CSR disclosure provisions in any Latin American setting.

CSR reporting research in the entire Latin American region appears to be scarce (Visser, 2008). Studies suggest that standards for CSR may not be well established among either multinational or local firms in Latin America and that CSR spending in the 


\section{Determinants of CSR disclosure in Mexico}

region is significantly lower compared to that in the home market (Torres-Baumgarten and Yucetepe, 2009). Araya (2006) finds evidence that a company's country of origin and industry of operation affect reporting choices. Vis-à-vis Mexico, Araya notes the limited nature of CSR reporting, suggesting cultural and historical factors as influences. These include a lack of disclosure regulation and a preference for command-and-control approaches; limited non-regulatory pressure, little media exposure, and a weak shareholder culture; a focus on costs; a 'confidentiality' culture; and stakeholders that have little legitimacy and few resources for exerting influence.

Most of the limited number of studies exploring CSR developments in Mexico focus on identifying disclosure patterns and trends and try to explore whether they reflect domestic demand or are influenced by international developments. In one of the earliest studies, Paul et al. (2006) conduct a content analysis of the corporate websites of a purposeful sample of 76 companies. They highlight the limited awareness of Mexican companies of CSR, which they primarily conceptualise in terms of philanthropy, although they also suggest that Mexican companies are moving towards global norms. In a follow-up study, Meyskens and Paul (2010) note some signs of CSR reporting development, although in contrast they also find only one company reporting to the Global Reporting Initiative (GRI) standards, which would suggest a limited international influence on the development of the country's reporting practice. The findings from both studies point towards a legitimacy based explanation, as they find increased CSR disclosure in industries vulnerable to social criticism, such as petroleum, cement and tobacco. Logsdon et al. (2006), however, distinguish between the CSR concept and practice: they find that the practice in Mexico is not new and that Mexico has recently experienced a growing awareness of the concept as well. They explain that the level of CSR reflects the particular social and political context and suggest that particular types of philanthropy have emerged as alternatives for government services. These findings are echoed by Weyzig's (2006) interview-based study, who also finds that the current CSR agenda is mostly associated with philanthropy. He attributes this to the country's catholic tradition while also noting that CSR is often associated with the promotion of products.

Subsequently, Muller and Kolk's (2009) study focusing in the auto parts industry, finds that CSR activities were comparable to those in developed countries. Their findings, however, seem to be limited by the focus of their study and do not seem to be generally applicable across sectors. To this point, the survey findings of Velásquez et al. (2009) suggest that the concept of CSR is still not well known. They note that CSR programmes are often perceived with suspicion and distrust, as survey respondents believe that companies use their privileged position to exploit poor and middle-class Mexicans. CSR programmes are also linked with tax evasion and some fraudulent activities.

More recently, Amezaga et al. (2013) focus on a sample of 150 Mexican business websites and find greater proportions of companies that present social responsibility indicators on their webpages, which suggests a performance-driven motivation behind CSR communications. They also interestingly break down among locally owned and foreign owned companies and find a greater proportion of multinational companies reporting value-driven and stakeholder-driven principles (Amezaga et al., 2013). Accordingly, Meyskens and Paul (2010) note that as the majority of Mexican firms are family-owned, they have traditionally valued discretion about the extent of their holdings and operations and may therefore be reluctant to publish CSR information. However, Meyskens and Paul also note that for subsidiaries or business partners of MNEs based in 


\section{Authors}

Europe or the USA, CSR has been managed and reported by corporate headquarters and is aimed at satisfying stakeholders who tend to focus on headquarters rather than operations in a relatively distant location such as Mexico. Likewise, Buccina et al. (2013) provide an example of how a parent company headquartered in the United States (Texaco/Chevron), managed its obligations in a less developed country (Ecuador) with little concern for local stakeholders (see also Hunter and Bansal, 2007, for related arguments). As Beddewela and Herzig (2013) also show (and are echoed by Belal et al., 2013), subsidiaries of multinational companies in less developed counties face the challenge of 'institutional duality': on the one hand, they seek internal legitimacy by conforming to regulations and policies of the head office, but on the other hand, they seek external legitimacy from local stakeholders of less developed countries. When these are in conflict, as the authors find, organisations prioritise the concerns of the head office and ignore those of the local stakeholders. This would suggest despite Amezaga's et al. (2013) findings, that foreign owned companies may solely be confined in publishing general CSR principles and assurances (or, as Weyzig, 2006 adds, information concerning health and safety), without extensively publishing relevant, more specific information about their CSR activities at the local community level.

\section{Theoretical framework}

The theoretical arguments of this study draw on stakeholder, accountability and legitimacy frameworks (and implicitly on signalling theory ${ }^{1}$ ) to explain how corporate governance can influence CSR reporting decisions. Although both the corporate governance and the CSR reporting research fields have been extensively analysed before, very few studies indeed have attempted to merge and identify interplays between them (Michelon and Parbonetti, 2012). Furthermore, as the succeeding discussion on hypotheses demonstrates, findings from that literature are largely inconclusive.

Stakeholder, legitimacy and accountability theories have all been previously utilised to explain corporate decisions to disclose CSR information, despite offering largely overlapping arguments (Gray et al., 1995). Gray et al. (1995) indicate that accountability involves two responsibilities or duties: the responsibility to undertake certain actions (or forbear from taking actions) and the responsibility to provide an account of these actions. Stakeholder theory would take these arguments further and suggest "the identification of

1 Signalling theory appears to be infrequently used in CSR reporting research (Vourvachis and Woodward, 2015) despite its intuitive appeal and widespread use in capital markets research (Asquith and Mullins, 1986; Leland and Pyle, 1977; Myers and Majluf, 1984; Ross, 1977). Although it is generally interpreted as being shareholdercentric (Woodward et al., 2001), in the CSR context, the theory would suggest that organisations signal their compliance to stakeholders by disclosing specific information; or potentially signal their 'excess' ethicality to gain a competitive advantage and subsequent economic benefits. However, signalling theory arguments in CSR research are often incorporated into stakeholder, accountability and legitimacy arguments, as the emphasis is on explaining corporate communications, which are predominantly voluntarily expressed, and therefore almost by definition, studies attempt to interpret motivations for corporate 'signals'. In this paper, the theory is more explicitly discussed when explaining the disclosure of positive vs. negative news in section 6 . 


\section{Determinants of CSR disclosure in Mexico}

those societal groups to whom the business might be considered accountable, and therefore to whom an adequate account of its activities would be deemed necessary" (Woodward and Woodward, 2001, p.1); Mitchell et al. (1997) extend these arguments by proposing a theory of stakeholder salience. This suggests that the degree to which managers prioritise competing stakeholder claims depends on the managerial perception of stakeholders' attributes, including their power to influence, and the urgency of their claims on, the firm as well as the stakeholder legitimacy. Legitimacy theory underlines the importance of a business to discharge its accountability duties to identified key stakeholders "in return for approval of its objectives, other rewards and ultimate survival" (Guthrie and Parker, 1989, p.344). Suchman (1995) identifies two major legitimacy theory variants: institutional legitimacy and strategic (or organisational) legitimacy. From an institutional perspective, attempts to legitimate are controlled by institutional pressures that create tendencies towards isomorphism within the organisational field (DiMaggio and Powell, 1983). From a strategic perspective, however, legitimacy can be influenced or manipulated by organisations to gain societal support (see, e.g., Dowling and Pfeffer, 1975; Lindblom, 1993).

Within the corporate governance domain, the above arguments would offer an alternative perspective to the conventional shareholder-centric one. This is reflected in Shleifer and Vishny's (1997) approach, suggesting that corporate governance “deals with the ways in which suppliers of finance to corporations assure themselves of getting a return on their investment” (p.737). A key associated objective would then be to mediate agency conflicts between management and shareholders. However, there are now increasing calls to "extend corporate accountability to non-shareholding stakeholder groups" (Brennan and Solomon, 2008, p.892). Indeed, more recent definitions of corporate governance emphasise the multiple accountability bonds of the organisations with their stakeholders (notably, OECD (2004) defines corporate governance "a set of relationships between firm's management, its board of directors, its shareholders and other stakeholders”). Such a broader accountability perspective would suggest that stakeholder engagement is essential to develop an understanding of stakeholders' expectations. A prerequisite for "good corporate governance and accountability” would then be to "focus on addressing these social, environmental, economic and ethical expectations" (Unerman and Bennett, 2004, p.685).

In line with the broader accountability perspective above, we argue that corporate governance and CSR disclosure can be seen as complementary mechanisms used by companies to enhance relations with key stakeholders and comply with institutional pressures. Figure 1 below graphically summarises our theoretical arguments and presents a modification of Michelon and Parbonetti's (2012) framework to more closely reflect the objectives of our study. We propose that corporate governance and stakeholder engagement can affect organisational legitimacy either directly or indirectly, by influencing CSR disclosure decisions. More specifically, and similar to Michelon and Parbonetti, we note that the board may be itself a mechanism of legitimacy and reputation (link A); however, the board may also decide on the definition of the accountability of the company (including identification of key stakeholders and other related organisational pressures), thereby also affecting the CSR disclosures reported to stakeholders and indirectly influencing the organisational legitimacy (link B). Likewise, stakeholder engagement may indirectly influence the levels of CSR information published by the organisation as part of its dialogue with stakeholders (link C); and directly enhance 


\section{Authors}

organisational legitimacy, as it allows organisations to adjust their behaviour to meet stakeholder expectations (link D).

To stress the importance of (the potential lack of) stakeholder engagement in the Mexican setting, we deviate from Michelon and Parbonetti by additionally acknowledging direct, two-way links between corporate governance and stakeholder engagement: corporate governance may determine the stakeholder engagement approach and how stakeholder's interests are considered at the board level, whereas stakeholders may, if they are consulted, have a direct input on board's decisions and occasionally control or appoint the board in more participative governance models. Stakeholders may also have an indirect input on the board's decisions through lobbying governmental decisions or by participating in other organisations and institutions that could put pressure on the firm. Such interactions would also ultimately be expected to influence the company's definition of accountability and CSR disclosure policies.

Prior to developing hypotheses to explore these arguments, we should note the distinction between substantive vs. symbolic legitimation, originally proposed by Pfeffer and colleagues (Pfeffer, 1981; Pfeffer and Salancik, 1978). 'Substantive' legitimation would generally involve "real, material change to organizational goals, structures and processes, or in socially institutionalized practices” (Savage et al., 2000, p.48). 'Symbolic' legitimation, however, involves the "transformation of the identity or meaning of acts to conform to social values" and is predicated on the proposal that "the acceptance of authority resides in the belief in the legitimacy of the order independently of the validity of that order" (Richardson, 1985, p.143, emphasis in the original). Previous studies exploring the linkages of corporate governance with CSR disclosure have not explored this distinction. By conducting a very thorough content analysis and additionally considering the quality of disclosure, we also offer some insights into related practices by Mexican companies.

\section{Hypotheses development}

To explore the applicability of our framework, we analyse the impact of several corporate governance dimensions on the extent of CSR disclosure. Specifically, we rely on factors related to the ownership structure, i.e., the presence of foreign owners, as well as the characteristics of governing bodies, such as the board composition, the board leadership, the board diversity and the board structure.

\subsection{Foreign ownership}

According to the agency theory, the presence of foreign investors increases dispersion of corporate ownership. In such circumstances, the different values and cultures and the geographical distance between owners and managers might increase the demand for information and transparency to monitor the managerial activities and ensure the continued inflows of capital (Haniffa and Cooke, 2005). In this regard, several studies find a positive association between foreign ownership and voluntary disclosure. For instance, Araya (2006) explored non-financial reporting in Latin America and found evidence of a positive link between company internationalisation and non-financial reporting. In the South, and South East, Asian context, Teoh and Thong's (1984), 


\section{Determinants of CSR disclosure in Mexico}

Chapple and Moon's (2005), and Muttakin and Subramaniam's (2015) findings suggest that companies with foreign ownership are more likely to provide more CSR disclosures.

However, this may not be the case for all types of disclosure. As per legitimacy and stakeholder theories, organisations may provide more CSR disclosure to address salient stakeholder concerns. Moreover, parent companies' directives on the subsidiaries operating in less developed economies often drive the latter's CSR disclosures (Belal et al., 2013). Thus, for foreign owners, disclosure about local stakeholders such as community may not be a priority, and related disclosure may therefore be decreased. Weyzig (2006) also accordingly notes that, despite the large amounts of foreign direct investment that Mexico has received, MNEs have established very few linkages with the local economy. Furthermore, the influence of foreign investments on disclosure practices might not be uniform across foreign investors. Different attributes of the foreign owners, such as investment orientations and preferences, therefore, might differently shape CSR reporting decisions. For instance, US foreign investors may not always be in favour of social investments, as many US parent companies have been involved in antisocial behaviours (Davis and Kim, 2007). Given also that US investors account for almost half of the foreign investment in Mexico (Santander, 2017) and the evidence suggesting the presence of 'institutional duality' in the less developed countries context (Beddewela and Herzig, 2013; Belal et al., 2013), we claim that the Mexican subsidiaries of foreign parent companies would tend to conform to regulations and policies of the head office rather than responding to the accountability needs of the local stakeholders.

We therefore hypothesise that, within the Mexican context:

H1: All being equal, CSR disclosure is negatively associated with foreign ownership.

\subsection{Board composition}

Independent directors are seen as accountability mechanisms as their role is to help in ensuring that companies are pursuing the interests not only of shareholders but also of stakeholders (Haniffa and Cooke, 2005; Zahra and Stanton, 1988). Because independent directors are less aligned with management, they may be more inclined to encourage firms to disclose a wider range of information to stakeholders, thus potentially conveying information to a broad set of stakeholders. In doing so, they also ensure congruence between organisational decisions and societal values and corporate legitimacy (Haniffa and Cooke, 2005; Michelon and Parbonetti, 2012). Independent directors may also have a personal incentive to encourage companies to commit to CSR and provide higher levels of related disclosure, as this will also benefit their prestige and role in society (Mallin et al., 2013).

Nevertheless, the findings of previous studies are not always conclusive about the type of relationship between the presence of independent directors and disclosure. On the one hand, there are studies suggesting a positive (Cerbioni and Parbonetti, 2007; Chen and Jaggi, 2000; Cheng and Courtenea, 2006; Karamanou and Vafeas, 2005; Muttakin and Subramaniam, 2015; Prado-Lorenzo et al., 2009 -or not significant relationship (Michelon and Parbonetti, 2012). On the other hand, some scholars have found a negative association (Eng and Mak, 2003; Forker, 1992; Haniffa and Cooke, 2005; Ho and Wong, 2001; Prado-Lorenzo and García-Sánchez, 2010).

We argue that the presence of independent directors is a key corporate governance dimension of Mexican companies. As most of these are family controlled, there is a high 


\section{Authors}

risk that the controlling family might make decisions to expropriate the firm wealth at the expense of minority shareholders. The latter would then rely on corporate disclosure to reveal and help prevent any potential opportunistic actions. From an agency perspective, therefore, we claim that the monitoring intensity of the board, as expressed by the increased presence of independent directors, should help constrain managerial discretion, resulting in a positive effect on firm CSR related reporting (Mallin et al., 2013). Thus, we hypothesise the following:

H2: All being equal, CSR disclosure is positively associated with the proportion of independent directors on the board.

\subsection{Board leadership: CEO duality}

CEO duality means that the CEO of a company also holds the board chairperson position. It has been argued that CEO duality constrains board independence and reduces the possibility that the board can properly execute its oversight and governance role (Cerbioni and Parbonetti, 2007). This could result in a lower level of voluntary disclosure and transparency. In this regard, in the EU or USA context, shareholder activists and regulators recommend the separation between the roles of CEO and chairman to help maintain impartiality of the board decision-making, reduce agency costs, and improve corporate performance.

Empirical research on the impact of CEO duality on voluntary disclosure has been inconclusive (Cheng and Courtenea, 2006; Ho and Wong, 2001: no association; Gul and Leung, 2004: negative association). In the CSR disclosure domain, Michelon and Parbonetti (2012) find no association, whilst Muttakin and Subramaniam (2015) find a negative association between CEO duality and CSR disclosure. In Mexico, however, given the dominance of the family control model, it is usual the founder or senior family member that is still tied to the company and serves as chairman of the board, while a younger family member acts as CEO (Husted and Serrano, 2002). This decreases the board's monitoring intensity and contributes to controlling family entrenchment, which, in turn, increases its ability to expropriate other non-family minority shareholders. Thus, the presence of CEO duality may actually have a negative impact on transparency and CSR reporting provision. Hence, we suggest the following:

H3: All being equal, CSR disclosure is negatively associated with CEO duality.

\subsection{Board gender}

Another important corporate governance dimension under examination is the board gender diversity. Although several definitions of diversity have been provided, including educational background, age and tenure of directors, one of the most commonly acknowledged is that concerned with the board gender diversity. From a stakeholder theory point of view, more gender-diverse groups might take a longer-term perspective and understand and relate to their stakeholders better. It has been argued that genderdiverse boards monitor more intensively, as female directors have better attendance records (which, in turn, ultimately benefits male director attendance) and women are also more likely to join board committees (Adams and Ferreira, 2009). According to the literature on gender-based differences, women and men are different in the way they play their leadership role: while men are characterised mainly by agentic attributes (Eagly et al., 2003), women are more ascribed to communal characteristics. Bilimoria (2000, p.27) 


\section{Determinants of CSR disclosure in Mexico}

suggests that women are valued as board members for their ability to "provide strategic input and generate productive discourse". Such abilities, combined with the communal characteristics predominant in female directors, are more likely to lead to the women's active involvement in issues of a strategic nature that concern the firm and its stakeholders (Mallin et al., 2013). Shaukat et al. (2016) also find that more genderdiverse firms achieve superior CSR performance. Given the discussed theoretical perspectives and findings, we suggest the following:

H4: All being equal, CSR disclosure is positively associated with board diversity.

\subsection{Board structure}

A company's board structure, as it defines its internal organisation and division of activities among committees, affects the directors' involvement in shaping the mission and the strategy of the company (Zahra and Pearce, 1989). The presence of a CSR committee or a person responsible for sustainability issues at the board level indicates that the company has an active strategic posture with regards to stakeholders (Michelon and Parbonetti, 2012; Ullmann, 1985). This committee has the responsibility to design and review the activity and processes that the company put in place to pursue CSR objectives (Post et al., 2002). The dissemination of information related to the social and environmental impact of company operations is one of the most important aspects of CSR policies. Several studies indeed find that there is a positive relationship between the presence of a CSR committee and CSR provision: e.g., Michelon and Parbonetti find (a weak) support, whereas Mallin et al. (2013) find that stakeholder-oriented governance mechanisms lead to higher environmental performance and eventually to more transparent environmental disclosure. We accordingly suggest the following:

H5: All being equal, CSR disclosure is positively associated with the presence of a CSR committee

\section{Research design}

\subsection{Sample selection}

To test our hypotheses, we originally identify all companies listed on the Mexican Stock Exchange (MSE), companies that voluntarily report to the General Reporting Initiative (GRI) and companies (private and public) drawn from the $2010 \mathrm{CNN}$ annual rankings of the 'The top 500 most admired companies in Mexico', which are well known and frequently referred to in the country. Our sampling approach is similar to that suggested by Gray et al. (1995), who propose that representative CSR samples should include the largest listed companies, a selection of companies from reliable rankings, and a selection of best practice exemplars ${ }^{1}$. We choose 2010 for our analysis, as this allows a sufficient

\footnotetext{
${ }^{1}$ We acknowledge that our sample selection strategy might be potentially affected by self-selection bias. However, our sampling approach is similar to that and, in fact, encompasses and expands the samples, of prior studies investigating CSR reporting in the Mexican setting (i.e., Meyskens and Paul, 2010; Paul et al., 2006) and can be considered representative of the population of Mexican firms.
} 


\section{Authors}

number of years for the corporate governance changes introduced by the revised Codes earlier in the decade to be applied (Machuga and Teitel, 2009) and provides a meaningful follow up for comparisons to the latest published content analysis survey conducted by Meyskens and Paul (2010) (which used data published four years earlier). From this sample, we excluded the companies that did not publish official reports in Spanish and those whose reports were impossible to find. We also excluded the companies for which we were unable to retrieve the data for our analyses. The total number of companies analysed is 73. Although our approach is largely similar to Meyskens and Paul's (2010), our sample compares favourably to their 27 companies analysed. Table 1 reports the breakdown of the sample according to industries. Notably, our sample identifies 34 companies reporting to GRI, compared to just one identified by Meyskens and Paul, highlighting the rapid increase in the adoption of the standard.

As reported in Table 1, the companies belong to nine different industries. Of the companies in our sample, $21 \%$ are from the Materials, $20.55 \%$ are from Consumer Staples, and $16.44 \%$ are from Manufacturing, while 15.07 are from Financial Services. Companies from Consumer Services, Telecommunication, Healthcare and Energy sector account for the rest of our sample.

\subsection{Measurement of variables}

\subsubsection{CSR disclosure}

To have a complete picture of the CSR reporting practices in Mexico, this paper examines CSR information disclosed by sampled companies through a wide array of reporting media including annual, social, environmental and sustainability reports of companies as well as other related web disclosure. This choice is due to the acknowledgement that an exclusive focus on annual reports may result in an incomplete representation of the CSR reporting practices. Several scholars note that over time, CSR reporting has evolved to stand-alone reports that include social, environmental, and financial information (Cho et al., 2015; Milne and Gray, 2007) and to other related disclosures that are disseminated through corporate websites (Adams and Frost, 2004; Guthrie et al., 2008; Patten and Crampton, 2003; Turner et al., 2006; Unerman and Bennett, 2004). All reports were in Spanish.

The analysis of CSR information disclosed through these three disclosure channels rely on content analysis, a methodology widely used in previous research on CSR (Milne and Adler, 1999; Vourvachis and Woodward, 2015) since it allows codifying large amounts of information into predefined categories and draws valid inferences from the pattern of reported data with a high level of objectivity and repeatability (Abbott and Monsen, 1979; Krippendorff, 1980). Specifically, following the trend of CSR researchers that employs volumetric approaches to content analysis, we rely on the proportions of a page as the recording unit (Adams et al., 1995; Hackston and Milne, 1996; Kuasirikun and Sherer, 2004; Murray et al., 2006). This choice is the most suitable for our research question, as it allows for capturing the large amount of valuable non-narrative CSR information (i.e., disclosed through charts, tables and photographs) generating detailed measurements and comparable findings across reports of the same and different companies (Patten and Crampton, 2003). To capture the volume of CSR, we followed the approach detailed in Gray et al. (1995) and Unerman (2000). Thus, an expert researcher 


\section{Determinants of CSR disclosure in Mexico}

conducted the analysis by utilising an A4 page size grid, which included twenty-five rows of equal height and four columns of equal width (resulting in the grid being divided in 100 cells of equal space). This was then applied across each piece of CSR information, counting the number of cells on the grid taken up by a disclosure (Unerman, 2000, p.676) and aggregating them into categories.

Following a well-established practice in CSR research (Cho and Patten, 2007; Patten, 2002), CSR information was first analysed against its content. To this aim, we used a modified version of the framework adopted by Gray et al. (1995) and Deegan et al. (2002) (Table 2, Panel A), details of which are provided in Appendix 1. Then, we recognised that this approach is insufficient to account for the complexity and multidimensionality of the CSR information that management can communicate (GRI, 2006). Hence, in addition to the content of CSR reporting, we drew on the semantic properties of the information.

Specifically, following prior research (Al-Tuwaijri et al., 2004; Beretta and Bozzolan, 2004; Michelon et al., 2015) and drawing on signalling theory, we considered (i) the economic sign that communicates the expected impact of the CSR activities on a company's future performance and (ii) the accuracy of information distinguishing whether the CSR activities are measured and described in monetary, numerical, declarative and pictorial terms. The economic sign allows us to distinguish firms that communicate negative information from the ones that disclose only positive or neutral information. Analysing the accuracy (nature/ type) of information permits us to differentiate the firms that disclose general boilerplate information from the ones that provide specific information that helps readers understand the CSR activities, objectives and results (Table 2, Panel B) ${ }^{1}$. From a signalling theory perspective, considering the economic sign and the accuracy of disclosure will assist in exploring whether organisations use CSR disclosure in a more transparent manner to communicate with stakeholders or whether they use it to manipulate perceptions and boost the related image. This methodology allowed both a total score for a company and various scores for more specific aspects of its disclosure to be built.

Based on the model in Table 2, for each disclosure media, we built 14 different scores of disclosures. The first six relate to the content of information disclosed: the disclosure index of Environmental (ENV), Energy (ENER), Employees (EMP), Market Place (MP), Community (COMM), Other (OTHER) information; the next three are related to the economic sign: the disclosure index of CSR information that has (1) a positive economic impact (POS), negative economic impact (NEG) or no impact (NEU). The last four

\footnotetext{
${ }^{1}$ For example, and drawing on Pemex's 2010 CSR report: when referring to a supply chain performance indicator as "result declined from 95\% in 2009 to 93\% in 2010" (p. 72), this is classified as negative and numerical. In contrast, a sentence such as: "the most important subjects of the social responsibility agenda are given in this report" (p. 8) is classified as positive and declarative. When introducing a table showing reduced employee numbers over the last three years (p. 60), this is classified as negative and numerical. On the opposite page, a table showing increased numbers of employees are trained in the code of ethics, is classified as positive and numerical. When including a graph with figures showing increased contributions to society (p. 88), this is classified as positive and monetary. And when dedicating a full page picture of a smiling employee at the workplace to introduce the topic of 'people development' (p. 56), this is classified as positive and pictorial.
} 


\section{Authors}

indices relate to the type of information used to discuss CSR activities, distinguishing among monetary (MON), numerical (NUM), declarative (DEC) and pictorial (PIC). Finally, for the annual report disclosure, we also computed a summary measure of the extent of CSR information relative to other non-CSR information (CSRINFO_AR).

This study relies on self-constructed disclosure indices to capture the cross-sectional variation of predominantly voluntary disclosure. Hence, given the degree of subjectivity and the potential for bias, it is necessary to perform various tests to assess their reliability as well as their internal and external validity. First, to reduce the variability across coders and improve the overall reliability of the disclosure indices, the coding process has been entirely conducted by one author. To ensure the reliability of the coded output, the coder first examines different examples of the various types of CSR information in company reports. Then, he/she performs a pilot analysis over a small sub-sample of companies in to validate the checklist and the decision rules. To mitigate the concern for disclosure indices' subjectivity, several tests are also performed assessing their internal and external validity. At this stage, all authors are involved and assist with the scrutiny of previous studies protocols as well as of widely accepted disclosure standards and definitions to ensure 'shared meanings' and accuracy of the results (Gray et al., 1995; Milne and Adler, 1999).

As regards internal validity, previous literature suggests that firm disclosure strategies are expected to be similar along all the disclosed items (Botosan, 1997). As a consequence, a correlation analysis among all the subcomponents of CSR disclosure score is performed to examine their internal consistency. Untabulated results report that the correlation coefficients for all the sub-components of the index are highly correlated with each other and with the overall CSR disclosure score, indicating a high level of internal consistency.

As a second validity test for the indices, this study explores the relationship between the level of disclosure and various firm characteristics (e.g., size, profitability, leverage). Un-tabulated results corroborate the validity of our disclosure indices in capturing the CSR disclosure levels for Mexican companies.

\subsubsection{Independent and control variables}

As for the independent variables concerned, we rely on several governance-related variables that according to the literature act as a proxy for the ownership and the board of directors' characteristics. Foreign ownership (FORE_OWN) is measured as a dummy variable, taking a value of 1 if the firm is owned by foreign shareholders and 0 otherwise (Choi et al., 2013). Following Cerbioni and Parbonetti (2007) and Mallin et al. (2013), board composition (B_INDEP) was measured by the proportion of independent directors, and the board gender (B_GEN) was measured by the proportion of women directors sitting on the board; board leadership (B_LEADER) was measured by a dummy variable that took a value of 1 if the CEO was also the chairperson of the board and 0 otherwise; and the board structure (B_STRUC) was measured by a dummy variable that took a value of 1 if the board of directors has a CSR or other sustainability-related committee and 0 otherwise. We also include the board size (B_SIZE) to account for the total number of directors sitting on the board (Jensen, 1993; Lipton and Lorsch, 1992). All the data on ownership and board of director attributes are collected from the firms' annual reports and corporate websites. 


\section{Determinants of CSR disclosure in Mexico}

We selected additional control variables on the basis of prior studies examining CSR disclosure. First, we consider whether and to what extent the company follows GRI Standards including an ordinal variable that ranges from 0 to 7 according to the level of GRI Compliance, as collected from the GRI website. Then, we control for the impact of the industry membership on CSR disclosure with a dummy variable (ESI) that equals 1 if the firm belongs to one of the environmental sensitive industries defined according to Patten (1991). We measure reputation (CSR_INDEX) as a dummy variable equal to 1 if the company belongs to the SR_MSE_INDEX; 0 otherwise (Deephouse and Carter, 2005; Michelon and Parbonetti, 2012), and as a measure of CSR performance (CSP), we consider whether the firm has ESR (Empresa Socialmente Responsable) Certification, which is well perceived in the country. Finally, we include some firm-specific variables that prior studies find to be associated with CSR disclosure. We control for leverage (LEV), measured as the ratio of total debt to shareholders equity (Ahmed and Courtis, 1999); company size (SIZE), measured as the logarithm of total assets (Jensen, 1993; Lipton and Lorsch, 1992) and firm profitability (ROA), for which the return on assets serves as a proxy. All variables are explained in detail in Table 3.

\subsection{Empirical analysis}

The empirical analysis develops through two phases. First, it assesses the extent of CSR disclosure for Mexican companies in three different disclosure media. For the purpose of this analysis, a t-test is performed for capturing the difference in mean values across AR, SR and web pages. Second, it identifies whether AR CSR disclosure is associated with corporate governance variables. For this analysis, we choose to focus on AR disclosure, given the pivotal role that it plays in corporate communication (Adams et al., 1998), as also supported by our findings. Moreover, CSR disclosure in AR is available for all the analysed companies, thus providing a wider examination of the relationship under investigation for the entire sample. To this aim, the following OLS regression model is estimated:

$$
\begin{aligned}
& \text { D_SCORE }=\beta_{0}+\beta_{1} \text { FORE_OWN }+\beta_{2} \text { B_INDEP }+\beta_{3} \text { B_GEN }+\beta_{4} \text { B_LEADER }+ \\
& +\beta_{5} \text { B_STRUC }+\sum_{\mathrm{k}}\left(\beta_{\mathrm{k}} \mathrm{CONT}_{\mathrm{k}}\right)+\varepsilon
\end{aligned}
$$

where D_SCORE is alternatively one of the disclosure indices described in Table 3 , Panel A and CONT is the vector of the selected control variables.

\section{Results}

\subsection{Comparisons across media}

The results of the analysis of the extent of disclosure are presented in Table 4. The table reports the comparison of mean CSR disclosure scores in annual reports (AR), sustainability reports (SR) and corporate web pages (WEB). Panel A displays the comparison across media for the content, and Panel B reports the comparison for the semantic properties.

For the content of CSR, our results report a significant difference for disclosure score among AR, SR and WEB. Specifically, we find that the type of CSR information 


\section{Authors}

companies choose to disclose on their annual report is significantly different from the ones that they disclose through SR and WEB. Indeed, the most discussed CSR themes in AR are Employees and Market Place, followed by Environment, Community and Energy. Conversely, SR is mainly used to convey information about Community, Environment and Employees, with less space devoted to Market Place and Energy disclosure. Similar patterns can be observed for WEB disclosure, although its disclosure scores on average are significantly lower than the ones observed for other reporting media. This evidence is in line with the findings of Patten and Crampton (2003) and Guthrie et al. (2008), suggesting that companies use disclosure media for different purposes.

The results of the comparison of disclosure scores related to semantic properties are even more interesting. We find that companies tend to use considerably more positive or neutral disclosures than negative ones. This is true for the annual reports, the SR and the WEB. However, the comparison across media shows that more positive disclosure is provided through web pages, followed by SR and then AR, and this difference is statistically significant for all three reporting media. We also report that negative disclosure is more prevalent in the AR relative to both SR and WEB. This finding is in line with Patten and Crampton (2003), and it is mainly because AR disclosure is mandatory-driven (and to a certain extent unavoidable), while disclosure in SR and WEB is predominantly voluntary and therefore offers more room for image building. Finally, concerning the accuracy of disclosure, we observe that CSR disclosure is mainly declarative in all the analysed reporting media. The average declarative disclosure score for WEB is significantly higher than those computed for SR and AR. Conversely, monetary information is more common in AR, but it is mostly absent in SR. Finally, the highest CSR disclosure score for pictorial information is observed in SR, and it is significantly different from the related AR and WEB disclosure score. The difference between the last two reporting media is not statistically significant. Overall, this evidence suggests that CSR information provided through AR is more accurate than the ones disclosed by other reporting media. Conversely, SR and web pages are used to convey boilerplate information, confirming that these media tend to be more symbolic, rather than substantive CSR reporting tools (Michelon et al., 2015).

Correlation results (untabulated) among disclosure indices show that there is a general positive correlation between the AR, SR and WEB disclosure measures. However, the correlation for the content disclosure scores is significant across the three reporting media, only for the information about Environment and Community, which highlights their importance to our sampled companies. A similar comment can be applied to the correlation between disclosure scores related to the semantic properties, where we find that there is a positive and significant correlation between the AR, SR and WEB only for positive and pictorial information. In general, these results suggest that companies include higher (lower) levels of CSR disclosure in their AR also tend to include higher (lower) levels of CSR disclosure on SR and web pages, although they also suggest that each medium serves a different purpose.

\subsection{Test of hypotheses}

Table 5 reports the descriptive statistics for the dependent and independent variables. The mean of the index for the overall disclosure is 0.0786 . The maximum value is 0.4432 , with a standard deviation of 0.0926 . Descriptive statistics for the disclosure score related to the content and the semantic properties of CSR information echo those reported in 


\section{Determinants of CSR disclosure in Mexico}

Table 4. For the governance-related variables, we observe that approximately $8 \%$ of the sample company has foreign ownership; 33\% of the board members are independent, and $4.6 \%$ are women, with the total number of directors sitting on the board being equal to 12. In almost $33 \%$ of the companies, the CEO is also the chairperson, and in $34.2 \%$ of the firms, the board has a CSR committee. For the independent variables, less than half of the sample companies report on the Application Level (22\%), have an ESR certification (34\%), or belong to a CSR index (26\%). Finally, the average sample company is large and has a positive performance.

The above findings are generally comparable to previous studies exploring governance determinants of voluntary disclosure and reflect the local context ${ }^{1}$. Muttakin and Subramaniam (2015) also report a similar percentage (9\%) of foreign ownership in their sample of Indian firms. Average board size is slightly larger than Adams and Ferreira's (2009) reported US board size of 10 and Cerbioni and Parbonetti's (2007) reported European board size of 8 . The percentage of duality is generally lower than that found in the US (56\% - Arena et al., 2015) but is considerably higher than the UK (4\% Shaukat et al., 2016), where it is against the recommendations of its governance code.

Notably, the proportion of independent directors in the sample is considerably lower compared to, e.g., Adams and Ferreira's (2009) 63\% [US], Cerbioni and Parbonetti's (2007) 56\% [Europe], Shaukat's et al. (2016) 52\% [UK], Haniffa and Cooke's (2005) 43\% [Malaysia], and Muttakin and Subramaniam's (2015) 41\% [India]. This is, however, in line with Husted and Serrano's (2002) and Orantes' (2016) corporate governance reviews of the Mexican setting, which provide similar indications of proportions and highlight the companies' strong family control and the associated challenges in director independence. It is noted, for example, that family members often occupy key management positions and serve on each other's boards, directors married to a member of the controlling family but not working for the company are considered independent, and godparents of family members are also considered independent (Machuga and Teitel, 2009). The percentage of women directors is also lower compared to, e.g., $8 \%$ found in the UK (Shaukat et al., 2016) and 8.5\% in the US (Adams and Ferreira, 2009), but is unsurprising given the generally low percentages of women managers noted in the region (Morrisson and Jütting, 2005).

Interestingly, the percentage of companies having a dedicated CSR committee is considerably higher than the $20 \%$ noted by Michelon and Parbonetti (2012) in their mixed European/US sample and the 16\% noted by Arena et al. (2015) in their US sample. Kolk (2008) also relatedly notes that only $11 \%$ of the largest US companies have a separate sustainability unit. This increased presence of CSR committees potentially reflects the deep-rooted indigenous cultural traditions of philanthropy, business ethics and community embeddedness in the region (Visser, 2008). However, as our analysis goes on to reveal, this is not associated with higher quality disclosure.

The Pearson correlation coefficients between independent and control variables reported in Table 6 do not suggest serious multicollinearity problems.

Tables 7 and 8 report the estimation for the association between the different disclosure indices and the test variables as well as the control variables. Column (1) of Table 7 shows the regression result for the overall CSR disclosure score. In line with our

${ }^{1}$ Certification and application measures are unique to this study, and there are no comparatives available in this stream of CSR reporting research. 


\section{Authors}

hypothesis, the board structure positively relates to the extent of CSR disclosure. This result, on the one hand, could signal that companies having a CSR committee are more engaged with the sustainability issues at the board level, and as a consequence, they are more likely to disseminate information concerning the CSR. On the other hand, it could suggest that the CSR committee and CSR disclosure are both symbolic means of acquiring stakeholder legitimacy and do not reflect a substantive commitment towards CSR.

For what concerns the other variables under investigation, we find that neither the foreign ownership nor the other board variables have a significant association with the overall CSR score. These results are is in line with prior disclosure studies (Beretta and Bozzolan, 2008), suggesting that the amount of CSR disclosure cannot be considered a good proxy of the firm's engagement in CSR policies and the related CSR reporting activities if we consider the overall amount of disclosure. In support of this interpretation, we also find that in our sample, variables that other studies consider as having a statistically significant effect on corporate voluntary disclosure are not related to the overall CSR disclosure score with only the exception of CSR_INDEX, which is positively and significantly related to the total CSR disclosure score. In particular, for the impact of foreign ownership, Araya (2006) also notes that foreign corporations do not report on their Latin American operations, as they typically report at the Group level and do not often provide performance information at the company level.

A different picture emerges from the analysis of the content of CSR information. With regard to the environmental information (Column 2), the regression model shows that, as expected, the disclosure score is positively and significantly related to the proportion of independent directors and the proportion of women directors as well as membership in environmentally sensitive industries. Hence, our results provide partial support for $\mathrm{H} 2$ and $H 4$, confirming that for Mexican companies, the effective monitoring provided by an independent and gender diverse board fosters the accountability of the firm towards the external environment. This is mainly due to the ability of an independent board to limit the attempts of the controlling family to expropriate the firm welfare, which in turn increases the disclosure transparency. In addition, the presence of women directors brings superior ethicality to the board, which translates into a higher level of information concerning the environmental impact of company activities. This beneficial effect is particularly relevant for environmental disclosure but is less important for social disclosure (employee and community), which by nature is usually more commonly found in these countries (Belal et al., 2013; Visser, 2008).

Conversely, information on Community (Column 6) is significantly and negatively related to the foreign ownership and the CSR index, while it is positively related to the economic performance. This evidence is in line with the findings of Amezaga et al. (2013) and Weyzig (2006) and supports our H1, suggesting that foreign-owned companies tend to provide information concerning general CSR principles without extensively publishing relevant and specific information about their CSR activities at the local community level. However, contrary to our expectation, Employee disclosure (Column 4) is significantly but negatively related to the board structure. This result seems to lend support to the interpretation that for Mexican companies, the CSR committee can be considered an instrumental legitimacy tool rather than as the means of ensuring real stakeholder engagement.

The disclosure of other CSR-related aspects of disclosure follows the same path as the total CSR disclosure score. 


\section{Determinants of CSR disclosure in Mexico}

Table 8 reports the results of the regression analysis that considers the semantic properties of the information disclosed. Regarding the economic sign of CSR information (Table 8, Columns 1-2-3), the results suggest that the disclosure of "good news" positively relates to the level of GRI compliance, while the release of neutral information significantly and negatively relates to the board independence, the board diversity and the GRI. No other governance variable is associated with the disclosure of good news and bad news. This evidence confirms that an independent and gender-diverse board helps provide a more informative CSR disclosure, as it might counterbalance the tendency to offer more positive disclosures than negative disclosure, which is more typical for companies located in less developed countries (Chapple and Moon, 2005).

As for the accuracy of the CSR information (Table 8, Column 4-5-6-7), we find that the disclosure of monetary information significantly and negatively relates to the board independence, the GRI and the economic performance. This result is counter-intuitive and can be explained in light of the high proprietary costs of CSR monetary information that leads Mexican companies to substitute CSR disclosure with a less costly governance mechanism (the independence of the board of directors in this case).

Further support for our hypothesis concerning the role of foreign investors comes from the evidence on numerical information, which is indeed significantly and negatively related to the presence of foreign ownership and both the CSP and the economic performance, while it is positively and significantly related to the GRI compliance. In contrast, the disclosure of declarative information is positively associated with the foreign ownership and membership in environmentally sensitive industries, suggesting that foreign investors decrease the propensity of their Mexican subsidiaries to publish substantial and informative CSR disclosure while they might increase their propensity to release unverifiable qualitative CSR information. Finally, the use of pictorial CSR information is significantly and positively associated with the board structure, which further suggests that the CSR committees in this setting are primarily a symbolic means of acquiring legitimacy.

Thus, our results suggest that corporate governance and CSR disclosure can be considered two complementary governance mechanisms, but only if we take into account the content of CSR information. If we look at the semantic properties of that information, our evidence points towards the symbolic use of CSR governance mechanisms, which presently leads to CSR disclosures that are less informative and accurate and, hence, of lower quality.

\section{Conclusions}

In summary, our findings support our theoretical framework by showing a general association between the governance variables and both the content and the semantic properties of CSR information published by Mexican companies, with their effect being different across the several disclosure categories analysed. Our findings suggest companies use CSR disclosure to gain legitimacy both by complying with institutional pressures towards isomorphism and by strategically influencing stakeholder perceptions to gain societal support.

With regard to the content of information, our findings are by and large consistent with an institutional legitimacy interpretation, predicting a complementary relationship of 


\section{Authors}

corporate governance and CSR disclosure towards satisfying stakeholder needs. Among the board-related variables, the presence of a CSR committee is one of the most relevant factors since it is related to the overall level of disclosure, the employee disclosure and to other CSR related disclosure. Additionally, the proportion of independent and women directors play a significant role in explaining the CSR information, particularly those related to the environmental dimension. This finding is in line with the arguments of Rao and Tilt (2015), who suggest that social information includes large parts that are regulated, particularly in the annual report, whereas environmental ones include more discretionary elements for female directors to potentially influence. Importantly, the presence of foreign ownership shows a significant and negative association with the community information. As regards the control variables, our results mostly confirm those of previous studies (Michelon and Parbonetti, 2012; Patten, 1991) pointing towards a relationship among the membership in the CSR Index and in environmentally sensitive industries with the content of CSR disclosure. The findings thus are consistent with an institutional legitimacy interpretation, whereby companies increase disclosure in response to stakeholder pressure.

As regards the economic sign of information, our results point towards a more strategic use of disclosure, whereby organisations attempt to manipulate legitimacy to gain societal support. We note that governance-related variables do not play an important role in explaining the disclosure of positive vs. negative information, although they show a negative association with the presence of neutral information. Moreover, the empirical results show that the accuracy of information is mostly related to the ownership structure of the firm. Indeed, companies with foreign ownership tend to reduce the use of numerical disclosures and to increase the amount of information provided in a declarative form. Conversely, among the board-related variables, we find that only the board independence and the board structure are relevant factors, although these results are partially surprising given that a more independent board provided with a CSR committee tends to release less monetary but more pictorial information. The results also seem to reinforce suggestions that companies voluntarily report to GRI to 'advertise' compliance. Our findings regarding the CSR committees give further credence to Rodrigue et al.'s (2013) interview-based findings, suggesting that environmental mechanisms are employed at the board level to protect the organisation from reputational and/or regulatory harm but are not necessarily intended to proactively improve environmental performance. Rodrigue et al.’s findings are from a USA setting, suggesting a potential regional isomorphic pattern when combined with the findings of this study. The findings regarding board independence may be explained due to the potential large presence of family-related directors on the board.

Our study also provides empirical credence to the previous literature, suggesting that foreign ownership may have a positive impact on types of disclosure such as the environment (Andrew et al., 1989; Teoh and Thong, 1984) but have a negative impact on community (e.g., Hunter and Bansal, 2007; Meyskens and Paul, 2010), suggesting that organisations face the challenge of institutional duality (Beddewela and Herzig, 2013). Foreign owners seem to neglect communications to local stakeholders in Mexico, to potentially prioritise salient stakeholders nearer headquarters (Mitchell et al., 1997). Given the dominance of the family ownership setting in the country and the generally high proportions of community disclosure overall, the findings may also point towards a link of family ownership with community disclosure, which is worth exploring further. To this direction point findings from Dyer and Whetten (2006), who in their S\&P500 


\section{Determinants of CSR disclosure in Mexico}

sample show that while family and non-family companies exhibit very similar types of 'positive' engagement with CSR, family firms have significantly fewer areas of negative social and environmental impact than their non-family counterparts, a finding that they attribute to the unwillingness of family companies to damage their reputation at local levels.

Overall, our findings suggest an increased international influence on Mexican CSR reporting, which creates tendencies towards isomorphism. Notwithstanding the dramatic increase in voluntary GRI compliance noted, we find Mexican companies disclose CSR information across all disclosure media, in a similar manner to their Western counterparts (Patten and Crampton, 2003). This suggests that perhaps contrasting findings in previous studies may be due to the sole focus on single examined media. Mexican organisations appear to adopt a 'pecking order' disclosure approach with regard to their reporting media, reporting their more substantive, positive (and negative) CSR news through the AR to their most 'critical stakeholders', whilst disclosing their largely symbolic (predominantly positive) CSR news in the more 'ephemeral' stand-alone reports, and the web, which potentially have smaller audiences, or audience of least importance. In this regard, introducing a mandatory integrated reporting requirement could potentially benefit the relevance and informativeness of Mexican companies' CSR disclosures, given the supporting evidence from South Africa (Solomon and Maroun, 2012). Moreover, although previous research has singled out the importance of charity, our findings also suggest the increasing emphasis on environmental disclosure. Interestingly and perhaps not unrelatedly, environmental concerns constitute the only area where it has been suggested that effective stakeholder consultation occurs (Weyzig, 2006).

While our results lend support to our revised Michelon and Parbonetti's (2012) framework, they also stress the importance of (the potential lack of) two of its instrumental parts, director independence and stakeholder engagement, in the Mexican setting. We note a considerably lower proportion of independent directors present in Mexico compared to other settings, although this may have also been affected by selfselection bias in our sampling strategy. The findings highlight the companies' strong family control, which compromises the board's independence and its effectiveness as a legitimacy-granting mechanism. We further find that even when companies tend to disclose more CSR information, their propensity to communicate is not only positive and boilerplate information but their negative and accurate disclosures is still low, suggesting that in our sample, there is still a widespread "ticking box" behaviour. Coupled with the findings from the CSR committees and foreign ownership above, this suggests that business engagement with CSR and its reporting is still weak in Mexico, which would further increase the audience's suspicion over the incentives of such communication. Both foreign investors and the domestic private sector need to engage more actively with stakeholders in order to make CSR action and communication more meaningful and genuinely instrumental in business conduct. 


\section{Authors}

\section{References}

Abbott, W.F. and Monsen, R.J. (1979) 'On the measurement of corporate social responsibility: selfreported disclosures as a method of measuring corporate social involvement', Academy of Management Journal, Vol. 22 No. 3, pp.501-515

Adams, C. and Frost, G. (2004) The Development of Corporate Web-Sites and Implications for Ethical, Social and Environmental Reporting through these Media, The Institute of Chartered Accountants of Scotland, Edinburgh.

Adams, C.A., Coutts, A. and Harte, G. (1995) 'Corporate equal opportunities (non-) disclosure', British Accounting Review, Vol. 27 No. 2, pp.87-108

Adams, C.A., Hill, W.Y. and Roberts, C.B. (1998) 'Corporate social reporting practices in western Europe: legitimating corporate behaviour?’ British Accounting Review, Vol. 30, pp.1-21

Adams, R.B. and Ferreira, D. (2009) 'Women in the boardroom and their impact on governance and performance', Journal of Financial Economics, Vol. 94 No. 2, pp.291-309

Ahmed, K. and Courtis, J.K. (1999) 'Associations between corporate characteristics and disclosure levels in annual reports: a meta-analysis', British Accounting Review, Vol. 31 No. 1, pp.35-61

Al-Tuwaijri, S.A., Christensen, T.E. and Hughes, K.E. (2004) 'The relations among environmental disclosure, environmental performance, and economic performance: a simultaneous equations approach', Accounting, Organizations and Society, Vol. 29 No. 5-6, pp.447-471

Amezaga, T.R.W., He, H.Y. and Cuervo, A.A.V. (2013) 'Socially responsible corporate communications in Mexico: evidence of the large companies by their operational levels', International Journal of Business and Management, Vol. 8 No. 10, pp.144-158

Andrew, B.H. et al. (1989) 'A note on corporate social disclosure practices in developing countries: the case of Malaysia and Singapore', British Accounting Review, Vol. 21 No. 4, pp.371-376

Arango, M. (2002) 'Philanthropy in Mexico: challenges and opportunities', ReVista: Harvard Business Review of Latin America, Vol. 1 No. 3, pp.33-37

Araya, M. (2006) 'Exploring tera incognita: non-financial reporting in corporate Latin America', Journal of Corporate Citizenship, Vol. 2006 No. 21, pp.25-38

Arena, C., Bozzolan, S. and Michelon, G. (2015) 'Environmental reporting: transparency to stakeholders or stakeholder manipulation? An analysis of disclosure tone and the role of the board of directors', Corporate Social Responsibility and Environmental Management, Vol. 22 No. 6, pp.346-361

Asquith, P. and Mullins, D.W. (1986) 'Equity issues and offering dilution', Journal of Financial Economics, Vol. 15 No. 1-2, pp.61-89

Baughn, C.C., Bodie, N.L. and McIntosh, J.C. (2007) 'Corporate social and environmental responsibility in Asian countries and other geographical regions', Corporate Social Responsibility and Environmental Management, Vol. 14 No. 4, pp.189-205

Baylis, R., Connell, L. and Flynn, A. (1998) 'Company size, environmental regulation and ecological modernization: further analysis at the level of the firm', Business Strategy and the Environment, Vol. 7 No. 5, pp.285-296

BBC News. (2002) 'Mexico’s 'devastating’ forest loss’', BBC News, 4 March

BBC News. (2012) 'Mexico’s president enacts climate change legislation', BBC News, 6 June.

Bebbington, J. (2004) 'Governance from the perspective of social/environmental accounting', Social and Environmental Accountability Journal, Vol. 24 No. 2, pp.15-18

Bebbington, J., Kirk, E.A. and Larrinaga, C. (2012) 'The production of normativity: a comparison of reporting regimes in Spain and the UK', Accounting, Organizations and Society, Vol. 37 No. 2, pp.78-94

Beddewela, E. and Herzig, C. (2013) 'Corporate social reporting by MNCs' subsidiaries in Sri Lanka', Accounting Forum, Vol. 37 No. 2, pp.135-149 


\section{Determinants of CSR disclosure in Mexico}

Belal, A.R., Cooper, S.M. and Roberts, R.W. (2013) 'Vulnerable and exploitable: the need for organisational accountability and transparency in emerging and less developed economies', Accounting Forum, Vol. 37 No. 2, pp.81-91

Beretta, S. and Bozzolan, S. (2004) 'A framework for the analysis of firm risk communication', International Journal of Accounting, Vol. 39 No. 3, pp.265-288

Beretta, S. and Bozzolan, S. (2008) 'Quality versus quantity: the case of forward-looking disclosure', Journal of Accounting, Auditing \& Finance, Vol. 23 No. 3, pp.333-376

Bilimoria, D. (2000) 'Building the business case for women corporate directors', in Burke, R.J. and Mattis, M.C. (Eds.), Women on Corporate Boards of Directors: International Challenges and Opportunities, Springer, New York, pp.25-40

Blowfield, M. and Murray, A. (2011) Corporate Responsibility, Oxford University Press, Oxford, UK

Botosan, C.A. (1997) 'Disclosure level and the cost of equity capital', The Accounting Review, Vol. 72 No. 3, pp.323-349

Brennan, N.M. and Solomon, J. (2008) 'Corporate governance, accountability and mechanisms of accountability: an overview', Accounting, Auditing \& Accountability Journal, Vol. 21 No. 7, pp.885-906

Buccina, S., Chene, D. and Gramlich, J. (2013) 'Accounting for the environmental impacts of Texaco's operations in Ecuador: Chevron's contingent environmental liability disclosures', Accounting Forum, Vol. 37 No. 2, pp.110-123

Cerbioni, F. and Parbonetti, A. (2007) 'Exploring the effects of corporate governance on intellectual capital disclosure: an analysis of European biotechnology companies', European Accounting Review, Vol. 16 No. 4, pp.791-826

Chapple, W. and Moon, J. (2005) 'Corporate social responsibility (CSR) in Asia', Business \& Society, Vol. 44 No. 4, pp.415-441

Chen, C.J.P. and Jaggi, B. (2000) 'Association between independent non-executive directors, family control and financial disclosure in Hong Kong', Journal of Accounting and Public Policy, Vol. 19, pp.285-310

Cheng, E.C.M. and Courtenea, S.M. (2006) 'Board composition, regulatory regime and voluntary disclosures in Hong Kong', Journal of Accounting and Public Policy, Vol. 19 No. 4/5, pp.285310

Cho, C.H. et al. (2015) 'Organized hypocrisy, organizational façades, and sustainability reporting', Accounting, Organizations and Society, Vol. 40, pp.78-94

Cho, C.H., Michelon, G. and Patten, D.M. (2012) 'Enhancement and obfuscation through the use of graphs in sustainability reports', Sustainability Accounting, Management and Policy Journal, Vol. 3 No. 1, pp.74-88

Cho, C.H. and Patten, D.M. (2007) 'The role of environmental disclosures as tools of legitimacy: a research note', Accounting, Organizations and Society, Vol. 32 No. 7-8, pp.639-647

Choi, J.J., Lam, K.C., Sami, H. and Zhou, H. (2013) 'Foreign ownership and information asymmetry’, Asia-Pacific Journal of Financial Studies, Vol. 42 No. 2, pp.141-166

Davis, F.F. and Kim, E.H. (2007) 'Business ties and proxy voting by mutual funds', Journal of Financial Economics, Vol. 85 No. 2, pp.552-570

Day, R. and Woodward, T. (2004) 'Disclosure of information about employees in the Directors' report of UK published financial statements: substantive or symbolic?' Accounting Forum, Vol. 28 No. 1, pp.43-59

Deegan, C., Rankin, M. and Tobin, J. (2002) 'An examination of the corporate social and environmental disclosures of BHP from 1983-1997', Accounting, Auditing \& Accountability Journal, Vol. 15 No. 3, pp.312-343

Deephouse, D.L. and Carter, S.M. (2005) 'An examination of differences between organizational legitimacy and organizational reputation', Journal of Management Studies, Vol. 42 No. 2, pp.329-360 


\section{Authors}

DiMaggio, P.J. and Powell, W.W. (1983) 'The iron cage revisited: institutional isomorphism and collective rationality in organizational fields', American Sociological Review, Vol. 48 No. 2, pp.147-160

Dowling, J. and Pfeffer, J. (1975) 'Organizational legitimacy: social values and organizational behavior', Pacific Sociological Review, Vol. 18 No. 1, pp.122-136

Dyer, W.G. and Whetten, D.A. (2006) 'Family firms and social responsibility: preliminary evidence from the S\&P 500', Entrepreneurship Theory and Practice, Vol. 30 No. 6, pp.785-802

Eagly, A.H., Johannesen-Schmidt, M.C. and van Engen, M.L. (2003) 'Transformational, transactional, and laissez-faire leadership styles: a meta-analysis comparing women and men', Psychological Bulletin, Vol. 129 No. 4, pp.569-591

Eng, L.L. and Mak, Y.T. (2003) 'Corporate governance and voluntary disclosure', Journal of Accounting and Public Policy, Vol. 22 No. 4, pp.325-345

Fallan, E. and Fallan, L. (2009) 'Voluntarism versus regulation', Journal of Accounting \& Organizational Change, Vol. 5 No. 4, pp.472-489

Fifka, M. (2012) 'The development and state of research on social and environmental reporting in global comparison', Journal für Betriebswirtschaft, Vol. 62 No. 1, pp.45-84

Forker, J.J. (1992) 'Corporate governance and disclosure quality', Accounting and Business Research, Vol. 22 No. 86, pp.111-124

Global Forest Watch. (2016) 'Tree cover loss, country rankings'. [online] http://www.globalforestwatch.org/countries/overview (Accessed 25 November 2016).

Gray, R., Kouhy, R. and Lavers, S. (1995) 'Corporate social and environmental reporting', Accounting, Auditing \& Accountability Journal, Vol. 8 No. 2, pp.47-77

GRI (Global Reporting Initiative). (2006) Sustainability Reporting Guidelines, V.3.0, Global Reporting Initiative, Amsterdam.

Gul, F.A. and Leung, S. (2004) 'Board leadership, outside directors' expertise and voluntary corporate disclosures', Journal of Accounting and Public Policy, Vol. 23 No. 5, pp.351-379

Guthrie, J., Cuganesan, S. and Ward, L. (2008) 'Disclosure media for social and environmental matters within the Australian food and beverage industry', Social and Environmental Accountability Journal, Vol. 28 No. 1, pp.33-44

Guthrie, J. and Parker, L.D. (1989) 'Corporate social reporting: a rebuttal of legitimacy theory', Accounting and Business Research, Vol. 19 No. 76, pp.343-352

Hackston, D. and Milne, M.J. (1996) 'Some determinants of social and environmental disclosures in New Zealand companies', Accounting, Auditing \& Accountability Journal, Vol. 9 No. 1, pp.77-108

Haniffa, R.M. and Cooke, T.E. (2005) 'The impact of culture and governance on corporate social reporting', Journal of Accounting and Public Policy, Vol. 24 No. 5, pp.391-430

Ho, S.S.M. and Wong, K.S. (2001) 'A study of the relationship between corporate governance structures and the extent of voluntary disclosure', Journal of International Accounting, Auditing and Taxation, Vol. 10 No. 2, pp.139-156

Hunter, T. and Bansal, P. (2007) 'How standard is standardized MNC global environmental communication?' Journal of Business Ethics, Vol. 71 No. 2, pp.135-147

Husted, B.W. and Serrano, C. (2002) 'Corporate governance in Mexico', Journal of Business Ethics, Vol. 37 No. 3, pp.337-348

Jensen, M.C. (1993) 'The modern industrial revolution, exit, and the failure of internal control systems', Journal of Finance, Vol. 48 No. 3, pp.831-880

Karamanou, I. and Vafeas, N. (2005) 'The association between corporate boards, audit committees, and management earnings forecasts: and empirical analysis', Journal of Accounting Research, Vol. 43 No. 3, pp.453-486

Khan, A., Muttakin, M.B. and Siddiqui, J. (2013) 'Corporate governance and corporate social responsibility disclosures: evidence from an emerging economy', Journal of Business Ethics, Vol. 114 No. 2, pp.207-223 


\section{Determinants of CSR disclosure in Mexico}

Kolk, A. (2008) 'Sustainability, accountability and corporate governance: exploring multinationals' reporting practices', Business Strategy and the Environment, Vol. 17 No. 1, pp.1-15

Kolk, A. and Pinkse, J. (2010) 'The integration of corporate governance in corporate social responsibility disclosures', Corporate Social Responsibility and Environmental Management, Vol. 17 No. 1, pp.15-26

KPMG. (2016) Currents of Change: The KPMG Survey of Corporate Responsibility Reporting 2015, KPMG International, The Netherlands.

Krippendorff, K. (1980) Content Analysis: An Introduction to its Methodology, Sage, New York, NY.

Kuasirikun, N. and Sherer, M. (2004) 'Corporate social accounting disclosure in Thailand', Accounting, Auditing \& Accountability Journal, Vol. 17 No. 4, pp.629-660

Larrinaga, C. et al. (2002) 'Accountability and accounting regulation: the case of the Spanish environmental disclosure standard', European Accounting Review, Vol. 11 No. 4, pp.723-740

Leland, H.E. and Pyle, D.H. (1977) 'Informational asymmetries, financial structure, and financial intermediation', Journal of Finance, Vol. 32 No. 2, pp.371-387

Lindblom, C.K. (1993) 'The implications of organizational legitimacy for corporate social performance and disclosure'. Paper presented at the Critical Perspectives on Accounting Conference. New York, NY

Lipton, M. and Lorsch, J.W. (1992) 'A modest proposal for improved corporate governance', Business Lawyer, Vol. 48 No. 1, pp.59-77

Logsdon, J.M., Thomas, D.E. and Van Buren, H.J. (2006) 'Corporate social responsibility in large Mexican firms', Journal of Corporate Citizenship, Vol. 2006 No. 21, pp.51-60

Luque-Vílchez, M. and Larrinaga, C. (2016) 'Reporting models do not translate well: failing to regulate CSR reporting in Spain', Social and Environmental Accountability Journal, Vol. 36 No. 1 , pp.56-75

Machuga, S. and Teitel, K. (2009) 'Board of director characteristics and earnings quality surrounding implementation of a corporate governance code in Mexico', Journal of International Accounting, Auditing and Taxation, Vol. 18 No. 1, pp.1-13

Mallin, C., Michelon, G. and Raggi, D. (2013) 'Monitoring intensity and stakeholders' orientation: how does governance affect social and environmental disclosure?' Journal of Business Ethics, Vol. 114 No. 1, pp.29-43

Matten, D. and Moon, J. (2008) "'Implicit" and "explicit" CSR: a conceptual framework for a comparative understanding of corporate social responsibility', Academy of Management Review, Vol. 33 No. 2, pp.404-424

Meyskens, M. and Paul, K. (2010) 'The evolution of corporate social reporting practices in Mexico', Journal of Business Ethics, Vol. 91 No. S2, pp.211-227

Michelon, G. and Parbonetti, A. (2012) 'The effect of corporate governance on sustainability disclosure', Journal of Management \& Governance, Vol. 16 No. 3, pp.477-509

Michelon, G., Pilonato, S. and Ricceri, F. (2015) 'CSR reporting practices and the quality of disclosure: an empirical analysis', Critical Perspectives on Accounting, Vol. 33, pp.59-78

Milne, M.J. and Adler, R.W. (1999) 'Exploring the reliability of social and environmental disclosures content analysis', Accounting, Auditing \& Accountability Journal, Vol. 12 No. 2, pp.237-256

Milne, M.J. and Gray, R. (2007) 'Future prospects for corporate sustainability reporting', in Unerman, J., Bebbington, J. and O'Dwyer, B. (Eds.), Sustainability Accounting and Accountability, Routledge, London, pp.184-207

Mitchell, R.K., Agle, B.R. and Wood, D.J. (1997) 'Toward a theory of stakeholder identification and salience: defining the principle of who and what really counts', Academy of Management Review, Vol. 22 No. 4, pp.853-886

Moon, J. (2014) 'Corporate governance and CSR', ESRC Seminar Series, 19 November, ACCA, London. 


\section{Authors}

Morrisson, C. and Jütting, J.P. (2005) 'Women's discrimination in developing countries: a new data set for better policies', World Development, Vol. 33 No. 7, pp.1065-1081

Muller, A. and Kolk, A. (2009) 'CSR performance in emerging markets evidence from Mexico', Journal of Business Ethics, Vol. 85 No. S2, pp.325-337

Murray, A. et al. (2006) 'Do financial markets care about social and environmental disclosure?' Accounting, Auditing \& Accountability Journal, Vol. 19 No. 2, pp.228-255

Muttakin, M.B. and Subramaniam, N. (2015) 'Firm ownership and board characteristics', Sustainability Accounting, Management and Policy Journal, Vol. 6 No. 2, pp.138-165

Myers, S.C. and Majluf, N.S. (1984) 'Corporate financing and investment decisions when firms have information that investors do not have', Journal of Financial Economics, Vol. 13 No. 2, pp.187-221

OECD. (2004) Principles of Corporate Governance, OECD, Paris.

Orantes, E.M. (2016) 'Corporate governance in Mexico: regulatory and institutional perspectives', in Ngwu, F.N., Osuji, O.K. and Stephen, F.H. (Eds.), Corporate Governance in Developing and Emerging Markets, Routledge, London, pp.140-159

Patten, D.M. (1991) 'Exposure, legitimacy, and social disclosure', Journal of Accounting and Public Policy, Vol. 10 No. 4, pp.297-308

Patten, D.M. (2000) 'Changing superfund disclosure and its relation to the provision of other environmental information', Advances in Environmental Accounting and Management, Vol. 1 No. 1, pp.101-121

Patten, D.M. (2002) 'The relation between environmental performance and environmental disclosure: a research note', Accounting, Organizations and Society, Vol. 27 No. 8, pp.763-773

Patten, D.M. and Crampton, W. (2003) 'Legitimacy and the internet: an examination of corporate web page environmental disclosures', in Freedman, M. and Jaggi, B. (Eds.), Advances in Environmental Accounting and Management, Elsevier, Oxford, UK, pp.31-57

Paul, K. et al. (2006) 'Corporate social reporting in Mexico', Journal of Corporate Citizenship, Vol. 2006 No. 22, pp.67-80

Pfeffer, J. (1981) 'Management as symbolic action: the creation and maintenance of organizational paradigms', in Cummings, L.L. and Staw, B.M. (Eds.), Research in Organizational Behavior, JAI Press, Greenwich, CT, pp.1-52

Pfeffer, J. and Salancik, G.R. (1978) The External Control of Organizations: A Resource Dependence Perspective, Harper \& Row, New York, NY

Plugge, L. (2008) Global Reporting Initiative: A Common Framework for Sustainability Reporting, CSR Asia, Singapore

Post, J.E., Preston, L.E. and Sachs, S. (2002) Redefining the corporation, stakeholder management and organizational wealth, Stanford University Press, Stanford, CT

Prado-Lorenzo, J.M., Gallego-Alvarez, I. and Garcia-Sanchez, I.M. (2009) 'Stakeholder engagement and corporate social responsibility reporting: the ownership effect', Corporate Social Responsibility and Environmental Management, Vol. 16 No. 2, pp.94-107

Prado-Lorenzo, J.M. and Garcia-Sanchez, I.M. (2010) 'The role of the board of directors in disseminating relevant information on greenhouse gases', Journal of Business Ethics, Vol. 97 No. 3, pp.391-424

Rao, K. and Tilt, C. (2015) 'Board composition and corporate social responsibility: the role of diversity, gender, strategy and decision making', Journal of Business Ethics, Vol. 138 No. 2, pp.327-347

Richardson, A.J. (1985) 'Symbolic and substantive legitimation in professional practice', Canadian Journal of Sociology, Vol. 10 No. 2, pp.139-152

Rodrigue, M., Magnan, M. and Cho, C.H. (2013) 'Is environmental governance substantive or symbolic? An empirical investigation', Journal of Business Ethics, Vol. 114 No. 1, pp.107-129

Ross, S.A. (1977) 'The determination of financial structure: the incentive-signalling approach', Bell Journal of Economics, Vol. 8 No. 1, pp.23-40 


\section{Determinants of CSR disclosure in Mexico}

$\begin{array}{llll}\text { Santander. (2017) 'Mexico: foreign } & \text { investment'. }\end{array}$ https://en.portal.santandertrade.com/establish-overseas/mexico/foreign-investment (Accessed 30 November 2017)

Savage, A., Cataldo, A.J. and Rowlands, J. (2000) 'A multi-case investigation of environmental legitimation in annual reports', Advances in Environmental Accounting \& Management, Vol. 1 No. 1, pp.45-81

Shaukat, A., Qiu, Y. and Trojanowski, G. (2016) 'Board attributes, corporate social responsibility strategy, and corporate environmental and social performance', Journal of Business Ethics, Vol. 135 No. 3, pp.569-585

Shleifer, A. and Vishny, R.W. (1997) 'A survey of corporate governance', Journal of Finance, Vol. 52 No. 2, pp.737-783

Solomon, J. and Maroon, W. (2012) Integrated reporting: the influence of King III on social, ethical and environmental reporting, ACCA, London.

Suchman, M.C. (1995) 'Managing legitimacy: strategic and institutional approaches', Academy of Management Review, Vol. 20 No. 3, pp.571-610

Teoh, H.-Y. and Thong, G. (1984) 'Another look at corporate social responsibility and reporting: an empirical study in a developing country', Accounting, Organizations and Society, Vol. 9 No. 2, pp.189-206

The Economist. (2012) 'Senores, start your engines', Special Report: Mexico, 24 November'.

The World Bank. (2012) 'Poverty and equity'. [online] http://povertydata.worldbank.org/poverty/country/MEX (Accessed 29 November 2016)

TheCatalist. (2010) 'Mexico 2050: the world's fifth largest economy'. [online] http://thecatalist.org/2010/03/mexico-2050-the-world's-fifth-largest-economy/ (Accessed 28 August 2016)

Torres-Baumgarten, G. and Yucetepe, V. (2009) 'Multinational firms' leadership role in corporate social responsibility in Latin America', Journal of Business Ethics, Vol. 85 No. S1, pp.217224

Turner, G., Vourvachis, P. and Woodward, T. (2006) 'Heading towards sustainability reporting: a pilot study into the progress of embracing the global reporting initiative in the United Kingdom', Journal of Applied Accounting Research, Vol. 8 No. 2, pp.41-70

Ullmann, A.A. (1985) 'Data in search of a theory: a critical examination of the relationships among social performance, social disclosure, and economic performance of U.S. firms', Academy of Management Review, Vol. 10 No. 3, pp.540-557

Unerman, J. (2000) 'Methodological issues - reflections on quantification in corporate social reporting content analysis', Accounting, Auditing \& Accountability Journal, Vol. 13 No. 5, pp.667-681

Unerman, J. and Bennett, M. (2004) 'Increased stakeholder dialogue and the internet: towards greater corporate accountability or reinforcing capitalist hegemony?' Accounting, Organizations and Society, Vol. 29 No. 7, pp.685-707

US Department of State. (2016) 'U.S. relations with Mexico', Factsheet, 12 July

Velásquez, L. et al. (2009) 'Mexico: an overview of CSR programmes', in Idowu, S.O. and Filho, W.L. (Eds.), Global Practices of Corporate Social Responsibility, Springer, Heidelbert, pp.273-283.

Visser, W. (2008) 'Corporate social responsibility in developing countries', in Crane, A.C., McWilliams, A., Matten, D., Moon, J. and Siegel, D.S. (Eds.), The Oxford Handbook of Corporate Social Responsibility, Oxford University Press, Oxford, UK, pp.473-499

Vourvachis, P. and Woodward, T. (2015) 'Content analysis in social and environmental reporting research: trends and challenges', Journal of Applied Accounting Research, Vol. 16 No. 2, pp.166-195

Weber, O. (2014) 'Environmental, social and governance reporting in China', Business Strategy and the Environment, Vol. 23 No. 5, pp.303-317 


\section{Authors}

Weyzig, F. (2006) 'Local and global dimensions of corporate social responsibility in Mexico', Journal of Corporate Citizenship, Vol. 2006 No. 24, pp.69-81

Woodward, D., Edwards, P. and Birkin, F. (2001) 'Some evidence on executives' views of corporate social responsibility', British Accounting Review, Vol. 33 No. 3, pp.357-397

Woodward, D. and Woodward, T. (2001) 'The case for a political economy of accounting: a critique of the arguments'. Paper Presented at the Conference the Case for a Political Economy of Accounting: A Critique of the Arguments. 26-28 March 2001. Nottingham.

Zahra, S.A. and Pearce, J.A. (1989) 'Boards of directors and corporate financial performance: a review and integrative model', Journal of Management, Vol. 15 No. 2, pp.291-334

Zahra, S.A. and Stanton, W.W. (1988) 'The implications of board of directors' composition for corporate strategy and performance', International Journal of Management, Vol. 5 No. 2, pp.229-236 
Determinants of CSR disclosure in Mexico

\section{Tables}

Table 1. Breakdown of sample for industry.

\begin{tabular}{lcc}
\hline Sector & Freq. & Percent \\
\hline Energy & 1 & 1.37 \\
Telecommunication & 6 & 8.22 \\
Financial Service & 11 & 15.07 \\
Consumer Discretional \& Services & 7 & 9.59 \\
Manufacturing & 12 & 16.44 \\
Healthcare & 5 & 6.85 \\
Materials & 16 & 21.92 \\
Consumer Staples & 15 & 20.55 \\
\hline & $\mathbf{7 3}$ & $\mathbf{1 0 0}$ \\
\hline
\end{tabular}


Authors

Table 2. Classification scheme: CSR disclosure and sematic properties.

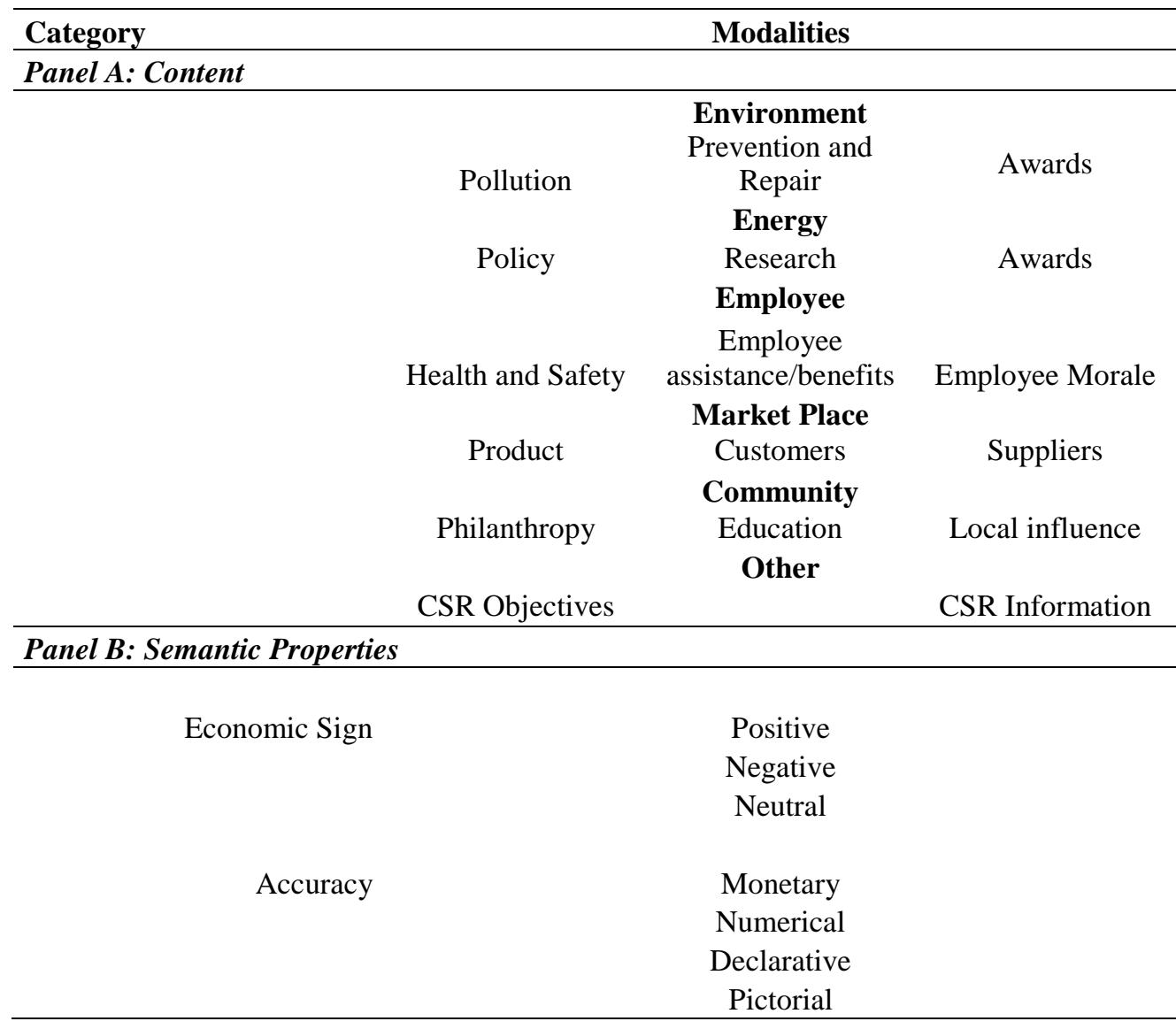


Determinants of CSR disclosure in Mexico

Table 3. Variable definition

\begin{tabular}{|c|c|c|}
\hline Variable & Label & Description \\
\hline \multicolumn{3}{|c|}{ Panel A: Disclosure Variables } \\
\hline CSRINFO_AR & Total CSR Disclosure Score & $\begin{array}{c}\text { Proportion of pages on CSR Disclosure in } \\
\text { Annual Report }\end{array}$ \\
\hline ENV_AR & $\begin{array}{l}\text { Environmental Disclosure } \\
\text { Score }\end{array}$ & $\begin{array}{l}\text { Proportion of pages in Annual Report } \\
\text { related with Environmental Information }\end{array}$ \\
\hline ENER_AR & Energy Disclosure Score & $\begin{array}{l}\text { Proportion of pages in Annual Report } \\
\text { related with Energy Information }\end{array}$ \\
\hline EMP_AR & Employee Disclosure Score & $\begin{array}{l}\text { Proportion of pages in Annual Report } \\
\text { related with Employee Information }\end{array}$ \\
\hline MP_AR & $\begin{array}{l}\text { Market Place Disclosure } \\
\text { Score }\end{array}$ & $\begin{array}{l}\text { Proportion of pages in Annual Report } \\
\text { related with Market Place Information }\end{array}$ \\
\hline COMM_AR & $\begin{array}{l}\text { Community Disclosure } \\
\text { Score }\end{array}$ & $\begin{array}{l}\text { Proportion of pages in Annual Report } \\
\text { related with Community Information }\end{array}$ \\
\hline OTHER_AR & Other Disclosure Score & $\begin{array}{l}\text { Proportion of pages in Annual Report } \\
\text { related with Other Information }\end{array}$ \\
\hline POS_AR & Positive Disclosure Score & $\begin{array}{l}\text { Proportion of pages in Annual Report } \\
\text { related with CSR Information with Positive } \\
\text { Impact on Firm Performance }\end{array}$ \\
\hline NEG_AR & Negative Disclosure Score & $\begin{array}{l}\text { Proportion of pages in Annual Report } \\
\text { related with CSR Information with } \\
\text { Negative Impact on Firm Performance }\end{array}$ \\
\hline NEU_AR & Neutral Disclosure Score & $\begin{array}{l}\text { Proportion of pages in Annual Report } \\
\text { related with CSR Information with Neutral } \\
\text { Impact on Firm Performance }\end{array}$ \\
\hline MON_AR & Monetary Disclosure Score & $\begin{array}{l}\text { Proportion of pages in Annual Report } \\
\text { related with CSR Disclosure with } \\
\text { Monetary Information }\end{array}$ \\
\hline NUM_AR & Numerical Disclosure Score & $\begin{array}{l}\text { Proportion of pages in Annual Report } \\
\text { related with CSR Disclosure with } \\
\text { Numerical Information }\end{array}$ \\
\hline DEC_AR & $\begin{array}{l}\text { Declarative Disclosure } \\
\text { Score }\end{array}$ & $\begin{array}{l}\text { Proportion of pages in Annual Report } \\
\text { related with CSR Disclosure with } \\
\text { Declarative Information }\end{array}$ \\
\hline D_PIC_AR & Pictorial Disclosure Score & $\begin{array}{l}\text { Proportion of pages in Annual Report } \\
\text { related with CSR Disclosure with Pictorial } \\
\text { Information }\end{array}$ \\
\hline \multicolumn{3}{|c|}{ Panel B: Independent and Control Variables } \\
\hline FORE_OWN & Foreign Ownership & $\begin{array}{l}\text { Dummy variable equals } 1 \text { if Foreign } \\
\text { ownership; } 0 \text { if Mexican ownership }\end{array}$ \\
\hline B_INDEP & Board Independence & $\begin{array}{c}\text { Proportion of Independent Directors Sitting } \\
\text { on the Board }\end{array}$ \\
\hline B_GEN & Board Gender & $\begin{array}{c}\text { Proportion of Women Directors Sitting on } \\
\text { the Board }\end{array}$ \\
\hline
\end{tabular}


Authors

\begin{tabular}{|c|c|c|}
\hline B_LEADER & Board Leadership & $\begin{array}{l}\text { Dummy variable equals } 1 \text { if CEO is also } \\
\text { the President; } 0 \text { Otherwise }\end{array}$ \\
\hline B_STRUC & Board Structure & $\begin{array}{c}\text { Dummy variable equals } 1 \text { if the Board of } \\
\text { Directors has a CSR Committee; } 0 \\
\text { otherwise }\end{array}$ \\
\hline BOD_SIZE & Board Size & Number of Directors Sitting on the Board \\
\hline GRI & GRI Compliance & $\begin{array}{c}\text { Ordinal variable from } 0 \text { to } 7 \text { for the level of } \\
\text { GRI Compliance }\end{array}$ \\
\hline CSR_INDEX & CSR Reputation & $\begin{array}{l}\text { Dummy variable equals } 1 \text { if the Firm } \\
\text { Belongs to SR_MSE_INDEX; } 0 \text { Otherwise }\end{array}$ \\
\hline ESI & Industry Membership & $\begin{array}{c}\text { Industry Membership to Environmental } \\
\text { Industries }\end{array}$ \\
\hline CSP & $\begin{array}{l}\text { Social and Environmental } \\
\text { Performance }\end{array}$ & $\begin{array}{c}\text { Dummy variable equals } 1 \text { if the Firm has } \\
\text { ESR Certification; } 0 \text { Otherwise }\end{array}$ \\
\hline SIZE & Firm Size & Natural Logarithm of Total Asset \\
\hline ROA & Firm Profitability & Operating Income Divided by Total Asset \\
\hline
\end{tabular}


Determinants of CSR disclosure in Mexico

Table 4. Comparison of mean CSR disclosure scores in sample companies' annual reports, sustainability reports and corporate web pages.

\begin{tabular}{lccccc}
\hline & $\begin{array}{c}\text { Annual } \\
\text { Report }\end{array}$ & Sustainability Report & Web Pages \\
\hline Panel A: Content & & & & & \\
\hline Environment & & & & & \\
Energy & 0.1267 & 0.2172 & $\circ$ & 0.1506 & $*, \wedge$ \\
Employee & 0.0189 & 0.0515 & $\circ$ & 0.0311 & \\
Market Place & 0.4515 & 0.1688 & $\circ$ & 0.1014 & $*, \wedge$ \\
Community & 0.1539 & 0.0814 & $\circ$ & 0.1218 & \\
Other & 0.0740 & 0.2250 & $\circ$ & 0.2134 & $*$ \\
& 0.1748 & 0.2558 & $\circ$ & 0.3814 & $*, \wedge$ \\
\hline Panel B: Semantic Properties & & & & & \\
\hline Positive & & & & & \\
Negative & 0.5569 & 0.8663 & $\circ$ & 0.9419 & $*, \wedge$ \\
Neutral & 0.0224 & 0.0080 & $\circ$ & 0.0021 & $\wedge$ \\
Monetary & 0.4205 & 0.1256 & $\circ$ & 0.0559 & $*, \wedge$ \\
Numerical & 0.2196 & 0.0041 & $\circ$ & 0 & $*, \wedge$ \\
Declarative & 0.0352 & 0.0516 & & 0.0148 & $*, \wedge$ \\
Pictorial & 0.5295 & 0.5935 & & 0.7501 & $*, \wedge$ \\
\hline
\end{tabular}

t-test is for difference in mean values across disclosure media

${ }^{\circ}$ denotes significance between AR and SR; * denotes significance between AR and WEB; ^

denotes significance between SR and WEB

significance at $10 \%$ (one-tailed) 
Authors

Table 5. Descriptive statistics.

\begin{tabular}{|c|c|c|c|c|c|c|}
\hline Variable & $\mathbf{N}$ & mean & p50 & $\min$ & $\max$ & sd \\
\hline \multicolumn{7}{|c|}{ Panel A: Disclosure Variables } \\
\hline CSRINFO_AR & 73 & 0.0786 & 0.0428 & 0.0028 & 0.4432 & 0.0926 \\
\hline ENV_AR & 73 & 0.1267 & 0.0598 & 0 & 0.9418 & 0.1674 \\
\hline ENER_AR & 73 & 0.0189 & 0 & 0 & 0.2680 & 0.0505 \\
\hline EMP_AR & 73 & 0.4515 & 0.4313 & 0 & 1 & 0.2920 \\
\hline MP_AR & 73 & 0.1539 & 0.0855 & 0 & 0.8 & 0.1707 \\
\hline COMMM_AR & 73 & 0.0740 & 0 & 0 & 0.6512 & 0.1332 \\
\hline OTHER_AR & 73 & 0.1748 & 0.0444 & 0 & 0.9665 & 0.2479 \\
\hline POS_AR & 73 & 0.5569 & 0.5811 & 0 & 1 & 0.3133 \\
\hline NEG_AR & 73 & 0.0224 & 0 & 0 & 0.6923 & 0.1110 \\
\hline NEU_AR & 73 & 0.4205 & 0.3853 & 0 & 1 & 0.3104 \\
\hline MON_AR & 73 & 0.2196 & 0.1424 & 0 & 1 & 0.2355 \\
\hline NUM_AR & 73 & 0.0352 & 0 & 0 & 0.4705 & 0.0791 \\
\hline DEC_AR & 73 & 0.5295 & 0.5 & 0 & 1 & 0.2653 \\
\hline PIC_AR & 73 & 0.2155 & 0.0986 & 0 & 0.7525 & 0.2500 \\
\hline \multicolumn{7}{|c|}{ Panel B: Independent and Control Variables } \\
\hline FORE_OWN & 73 & 0.0821 & 0 & 0 & 1 & 0.2765 \\
\hline B_INDEP & 73 & 0.3300 & 0.375 & 0 & 0.8571 & 0.2383 \\
\hline B_GEN & 73 & 0.0464 & 0 & 0 & 0.3636 & 0.0733 \\
\hline B_LEADER & 73 & 0.3287 & 0 & 0 & 1 & 0.4730 \\
\hline B_STRUC & 73 & 0.3424 & 0 & 0 & 1 & 0.4778 \\
\hline BOD_SIZE & 73 & 12.4383 & 12 & 5 & 32 & 4.6097 \\
\hline GRI & 73 & 1.0684 & 0 & 0 & 7 & 2.2566 \\
\hline CSR_INDEX & 73 & 0.2602 & 0 & 0 & 1 & 0.4418 \\
\hline ESI & 73 & 0.2328 & 0 & 0 & 1 & 0.4255 \\
\hline CSP & 73 & 0.3424 & 0 & 0 & 1 & 0.4778 \\
\hline SIZE & 73 & 10.1801 & 10.1801 & 5.3386 & 14.1022 & 1.8181 \\
\hline ROA & 73 & 0.0984 & 0.0767 & 0.0032 & 0.3579 & 0.0803 \\
\hline
\end{tabular}


Int. J. хххххххххх хххххххххххххххтs, Vol. X, No. Y, хxхx

Table 6. Correlation coefficients.

\begin{tabular}{|c|c|c|c|c|c|c|c|c|c|c|c|c|}
\hline & FORE_OWN & B_INDEP & B_GEN & B_LEADER & B_STRUC & BOD_SIZE & GRI & CSR_INDEX & ESI & CSP & SIZE & ROA \\
\hline FORE_OWN & 1 & & & & & & & & & & & \\
\hline B_INDEP & -0.0043 & 1 & & & & & & & & & & \\
\hline B_GEN & 0.1496 & $-0.2236^{*}$ & 1 & & & & & & & & & \\
\hline B_LEADER & -0.1033 & -0.0468 & -0.0259 & 1 & & & & & & & & \\
\hline B_STRUC & -0.0058 & -0.0073 & 0.1607 & -0.1364 & 1 & & & & & & & \\
\hline BOD_SIZE & 0.1566 & 0.1805 & 0.0342 & -0.1180 & 0.0948 & 1 & & & & & & \\
\hline GRI & 0.1021 & $-0.1959 *$ & 0.0625 & -0.0474 & $0.2098 *$ & $0.1960 *$ & 1 & & & & & \\
\hline CSR_INDEX & 0.0498 & 0.0351 & 0.1248 & -0.1493 & 0.1640 & 0.1751 & $0.3719 *$ & 1 & & & & \\
\hline ESI & -0.0469 & -0.1166 & $-0.2829 *$ & -0.1096 & 0.0805 & -0.1660 & $0.3013^{*}$ & -0.0314 & 1 & & & \\
\hline CSP & 0.0993 & -0.0635 & 0.1940 & -0.0135 & $0.2092 *$ & $0.2714^{*}$ & $0.3644^{*}$ & $0.2298 *$ & $0.2171^{*}$ & 1 & & \\
\hline SIZE & $0.3123^{*}$ & -0.1789 & 0.0374 & $-0.2074 *$ & 0.0713 & $0.4373^{*}$ & $0.4124^{*}$ & $0.3565^{*}$ & -0.0290 & $0.2543^{*}$ & 1 & \\
\hline ROA & 0.0646 & -0.0028 & 0.0612 & -0.1175 & 0.1654 & $0.1987^{*}$ & $0.1987 *$ & $0.2422^{*}$ & 0.0449 & 0.1598 & 0.0621 & 1 \\
\hline
\end{tabular}


Int. J. хxхxхxхxхxх хxхxхxхxхxхxxxхms, Vol. X, No. Y, xxxx

Table 7. Regression results for CSR disclosure scores related to content.

(1) (2) (3)

(4) (6) (6)

(7)

VARIABLES CSRINFO_AR ENV_AR ENER_AR EMP_AR MP_AR COMM_AR OTHER_AR

\begin{tabular}{|c|c|c|c|c|c|c|c|}
\hline \multirow[t]{2}{*}{ FORE_OWN } & 0.0508 & 0.00672 & -0.00239 & -0.104 & 0.129 & $-0.0949 * *$ & 0.0656 \\
\hline & $(0.0425)$ & $(0.0575)$ & $(0.0215)$ & $(0.107)$ & $(0.129)$ & $(0.0452)$ & $(0.107)$ \\
\hline \multirow[t]{2}{*}{ B_INDEP } & 0.0126 & 0.151* & 0.0301 & -0.124 & -0.0235 & -0.00508 & -0.0287 \\
\hline & $(0.0467)$ & $(0.0759)$ & $(0.0256)$ & $(0.140)$ & $(0.101)$ & $(0.0806)$ & $(0.118)$ \\
\hline \multirow[t]{2}{*}{ B_GEN } & -0.0442 & $0.659^{* *}$ & 0.00640 & -0.145 & -0.0665 & -0.116 & -0.339 \\
\hline & $(0.174)$ & $(0.279)$ & $(0.0694)$ & $(0.552)$ & $(0.314)$ & $(0.225)$ & $(0.459)$ \\
\hline \multirow[t]{2}{*}{ B_LEADER } & -0.0134 & -0.0460 & 0.00660 & -0.0710 & 0.0541 & 0.0164 & 0.0399 \\
\hline & $(0.0214)$ & $(0.0434)$ & $(0.0120)$ & $(0.0781)$ & $(0.0446)$ & $(0.0351)$ & $(0.0605)$ \\
\hline \multirow[t]{2}{*}{ B_STRUC } & $0.0420 * *$ & -0.00145 & 0.0193 & $-0.141^{*}$ & 0.0253 & -0.00469 & 0.102* \\
\hline & $(0.0195)$ & $(0.0427)$ & $(0.0167)$ & $(0.0710)$ & $(0.0472)$ & $(0.0366)$ & $(0.0562)$ \\
\hline \multirow[t]{2}{*}{ BOD_SIZE } & -0.00199 & -0.00447 & $-6.24 \mathrm{e}-05$ & 0.00537 & -0.00189 & 0.00628 & -0.00523 \\
\hline & (0.00247) & $(0.00525)$ & $(0.00105)$ & $(0.00885)$ & $(0.00574)$ & $(0.00483)$ & $(0.00543)$ \\
\hline \multirow[t]{2}{*}{ GRI } & -0.00255 & 0.00382 & 0.00456 & 0.00395 & 0.000143 & 0.00157 & -0.0140 \\
\hline & $(0.00514)$ & $(0.00800)$ & $(0.00366)$ & $(0.0171)$ & $(0.0120)$ & $(0.00692)$ & (0.0137) \\
\hline \multirow[t]{2}{*}{ CSR_INDEX } & 0.0725* & -0.0643 & 8.95e-05 & -0.107 & -0.00612 & $-0.0793^{*}$ & $0.256 * * *$ \\
\hline & $(0.0406)$ & $(0.0449)$ & $(0.0152)$ & $(0.0995)$ & $(0.0469)$ & $(0.0414)$ & $(0.0902)$ \\
\hline \multirow[t]{2}{*}{ ESI } & -0.0180 & $0.136 * *$ & 0.0204 & -0.00711 & -0.0615 & -0.0150 & -0.0729 \\
\hline & $(0.0221)$ & $(0.0613)$ & (0.0159) & $(0.0875)$ & $(0.0622)$ & $(0.0336)$ & $(0.0507)$ \\
\hline \multirow[t]{2}{*}{ CSP } & -0.0167 & -0.00851 & -0.00760 & 0.0329 & 0.00499 & 0.0156 & -0.0374 \\
\hline & $(0.0209)$ & $(0.0654)$ & $(0.0115)$ & $(0.0863)$ & $(0.0514)$ & $(0.0437)$ & $(0.0564)$ \\
\hline \multirow[t]{2}{*}{ SIZE } & -0.00274 & 0.00422 & 0.00404 & -0.0100 & -0.00209 & 0.00846 & -0.00460 \\
\hline & $(0.00643)$ & $(0.0140)$ & $(0.00434)$ & $(0.0254)$ & $(0.0184)$ & $(0.0107)$ & $(0.0185)$ \\
\hline \multirow[t]{2}{*}{ ROA } & 0.0143 & -0.189 & -0.0334 & -0.579 & 0.186 & $0.524^{*}$ & 0.0916 \\
\hline & $(0.117)$ & $(0.186)$ & $(0.0718)$ & $(0.374)$ & $(0.252)$ & $(0.275)$ & (0.343) \\
\hline \multirow[t]{2}{*}{ Constant } & 0.108 & 0.0766 & -0.0440 & $0.685 * * *$ & 0.168 & -0.114 & 0.227 \\
\hline & $(0.0684)$ & $(0.175)$ & $(0.0380)$ & $(0.245)$ & $(0.176)$ & $(0.131)$ & $(0.193)$ \\
\hline Observations & 73 & 73 & 73 & 73 & 73 & 73 & 73 \\
\hline R-squared & 0.198 & 0.212 & 0.155 & 0.149 & 0.091 & 0.224 & 0.240 \\
\hline Max VIF & & & & 1.89 & & & \\
\hline
\end{tabular}

Copyright @ 201x Inderscience Enterprises Ltd. 
Determinants of CSR disclosure in Mexico

Table 8. Regression results for CSR disclosure scores related to semantic properties.

\begin{tabular}{|c|c|c|c|c|c|c|c|}
\hline VARIABLES & $\begin{array}{c}(1) \\
\text { POS_AR }\end{array}$ & $\begin{array}{c}(2) \\
\text { NEG_AR }\end{array}$ & $\begin{array}{c}\text { (3) } \\
\text { NEU_AR }\end{array}$ & $\begin{array}{c}(4) \\
\text { MON_AR }\end{array}$ & $\begin{array}{c}(5) \\
\text { NUM_AR }\end{array}$ & $\begin{array}{c}(6) \\
\text { DEC_AR }\end{array}$ & $\begin{array}{c}\text { (7) } \\
\text { PIC_AR }\end{array}$ \\
\hline FORE_OWN & $\begin{array}{r}-0.0322 \\
(0.142)\end{array}$ & $\begin{array}{c}-0.000286 \\
(0.0399)\end{array}$ & $\begin{array}{l}0.0325 \\
(0.124)\end{array}$ & $\begin{array}{l}-0.0764 \\
(0.0751)\end{array}$ & $\begin{array}{c}\mathbf{- 0 . 0 4 8 0} * * \\
(0.0219)\end{array}$ & $\begin{array}{c}\text { 0.276** } \\
(0.119)\end{array}$ & $\begin{array}{c}-0.152 \\
(0.0935)\end{array}$ \\
\hline B_INDEP & $\begin{array}{c}0.206 \\
(0.164)\end{array}$ & $\begin{array}{c}0.0948 \\
(0.0628)\end{array}$ & $\begin{array}{c}-\mathbf{0 . 3 0 1} * \\
(0.161)\end{array}$ & $\begin{array}{c}-\mathbf{0 . 2 9 2 * *} \\
(0.124)\end{array}$ & $\begin{array}{c}0.0676 \\
(0.0504)\end{array}$ & $\begin{array}{c}0.123 \\
(0.133)\end{array}$ & $\begin{array}{c}0.101 \\
(0.122)\end{array}$ \\
\hline B_GEN & $\begin{array}{c}0.800 \\
(0.555)\end{array}$ & $\begin{array}{c}0.271 \\
(0.230)\end{array}$ & $\begin{array}{c}\mathbf{- 1 . 0 7 1} * \\
(0.566)\end{array}$ & $\begin{array}{l}-0.604 \\
(0.499)\end{array}$ & $\begin{array}{l}0.0638 \\
(0.103)\end{array}$ & $\begin{array}{c}0.413 \\
(0.632)\end{array}$ & $\begin{array}{c}0.127 \\
(0.548)\end{array}$ \\
\hline B_LEADER & $\begin{array}{l}-0.0583 \\
(0.0886)\end{array}$ & $\begin{array}{c}0.0533 \\
(0.0369)\end{array}$ & $\begin{array}{l}0.00494 \\
(0.0879)\end{array}$ & $\begin{array}{l}-0.0702 \\
(0.0594)\end{array}$ & $\begin{array}{l}0.00185 \\
(0.0241)\end{array}$ & $\begin{array}{c}0.0598 \\
(0.0649)\end{array}$ & $\begin{array}{l}0.00857 \\
(0.0707)\end{array}$ \\
\hline B_STRUC & $\begin{array}{c}0.0766 \\
(0.0764)\end{array}$ & $\begin{array}{l}-0.0297 \\
(0.0194)\end{array}$ & $\begin{array}{l}-0.0469 \\
(0.0761)\end{array}$ & $\begin{array}{l}-0.0138 \\
(0.0604)\end{array}$ & $\begin{array}{l}-0.0249 \\
(0.0189)\end{array}$ & $\begin{array}{l}-0.0825 \\
(0.0660)\end{array}$ & $\begin{array}{c}\mathbf{0 . 1 2 1}^{*} \\
(0.0634)\end{array}$ \\
\hline BOD_SIZE & $\begin{array}{l}-0.00957 \\
(0.0100)\end{array}$ & $\begin{array}{l}-0.00300 \\
(0.00292)\end{array}$ & $\begin{array}{c}0.0126 \\
(0.00943)\end{array}$ & $\begin{array}{c}0.00352 \\
(0.00633)\end{array}$ & $\begin{array}{l}-0.00120 \\
(0.00159)\end{array}$ & $\begin{array}{l}-0.00835 \\
(0.00687)\end{array}$ & $\begin{array}{c}0.00603 \\
(0.00738)\end{array}$ \\
\hline GRI & $\begin{array}{l}\text { 0.0291* } \\
(0.0174)\end{array}$ & $\begin{array}{l}0.000598 \\
(0.00281)\end{array}$ & $\begin{array}{l}-\mathbf{0 . 0 2 9 7} * \\
(0.0175)\end{array}$ & $\begin{array}{l}-\mathbf{0 . 0 2 2 8} * \\
(0.0132)\end{array}$ & $\begin{array}{c}\mathbf{0 . 0 1 0 8}^{*} \\
(0.00592)\end{array}$ & $\begin{array}{l}0.00365 \\
(0.0180)\end{array}$ & $\begin{array}{l}0.00838 \\
(0.0152)\end{array}$ \\
\hline CSR_INDEX & $\begin{array}{l}-0.102 \\
(0.105)\end{array}$ & $\begin{array}{c}0.0107 \\
(0.0232)\end{array}$ & $\begin{array}{l}0.0911 \\
(0.101)\end{array}$ & $\begin{array}{l}-0.0820 \\
(0.0597)\end{array}$ & $\begin{array}{c}0.0352 \\
(0.0277)\end{array}$ & $\begin{array}{c}0.0715 \\
(0.0880)\end{array}$ & $\begin{array}{l}-0.0247 \\
(0.0936)\end{array}$ \\
\hline ESI & $\begin{array}{r}-0.0127 \\
(0.105)\end{array}$ & $\begin{array}{c}0.0716 \\
(0.0480)\end{array}$ & $\begin{array}{l}-0.0589 \\
(0.0959)\end{array}$ & $\begin{array}{l}-0.0934 \\
(0.0699)\end{array}$ & $\begin{array}{c}0.0129 \\
(0.0250)\end{array}$ & $\begin{array}{c}\mathbf{0 . 1 3 7 *} \\
(0.0727)\end{array}$ & $\begin{array}{l}-0.0563 \\
(0.0650)\end{array}$ \\
\hline CSP & $\begin{array}{c}0.0442 \\
(0.0931)\end{array}$ & $\begin{array}{l}-0.0242 \\
(0.0224)\end{array}$ & $\begin{array}{l}-0.0201 \\
(0.0904)\end{array}$ & $\begin{array}{c}0.102 \\
(0.0732)\end{array}$ & $\begin{array}{c}\mathbf{- 0 . 0 2 7 3} * \\
(0.0148)\end{array}$ & $\begin{array}{l}-0.0725 \\
(0.0771)\end{array}$ & $\begin{array}{r}-0.00269 \\
(0.0835)\end{array}$ \\
\hline SIZE & $\begin{array}{c}0.0215 \\
(0.0269)\end{array}$ & $\begin{array}{l}-0.00481 \\
(0.0129)\end{array}$ & $\begin{array}{l}-0.0167 \\
(0.0260)\end{array}$ & $\begin{array}{l}0.00854 \\
(0.0187)\end{array}$ & $\begin{array}{c}0.00627 \\
(0.00710)\end{array}$ & $\begin{array}{l}-0.0122 \\
(0.0242)\end{array}$ & $\begin{array}{r}-0.00261 \\
(0.0184)\end{array}$ \\
\hline ROA & $\begin{array}{l}0.0941 \\
(0.428)\end{array}$ & $\begin{array}{c}0.00734 \\
(0.150)\end{array}$ & $\begin{array}{l}-0.101 \\
(0.405)\end{array}$ & $\begin{array}{c}-\mathbf{0 . 5 9 3} * * \\
(0.295)\end{array}$ & $\begin{array}{c}-\mathbf{0 . 1 7 8} * \\
(0.0964)\end{array}$ & $\begin{array}{c}0.471 \\
(0.454)\end{array}$ & $\begin{array}{c}0.300 \\
(0.344)\end{array}$ \\
\hline Constant & $\begin{array}{c}0.321 \\
(0.250)\end{array}$ & $\begin{array}{l}0.0449 \\
(0.117)\end{array}$ & $\begin{array}{c}\mathbf{0 . 6 3 4} * * \\
(0.248)\end{array}$ & $\begin{array}{c}\text { 0.338* } \\
(0.192)\end{array}$ & $\begin{array}{l}-0.0239 \\
(0.0773)\end{array}$ & $\begin{array}{c}\mathbf{0 . 6 0 8} * * \\
(0.263)\end{array}$ & $\begin{array}{l}0.0779 \\
(0.208)\end{array}$ \\
\hline Observations & 73 & 73 & 73 & 73 & 73 & 73 & 73 \\
\hline R-squared & 0.133 & 0.192 & 0.142 & 0.252 & 0.245 & 0.202 & 0.139 \\
\hline Max VIF & & & & 1.89 & & & \\
\hline
\end{tabular}


Figures

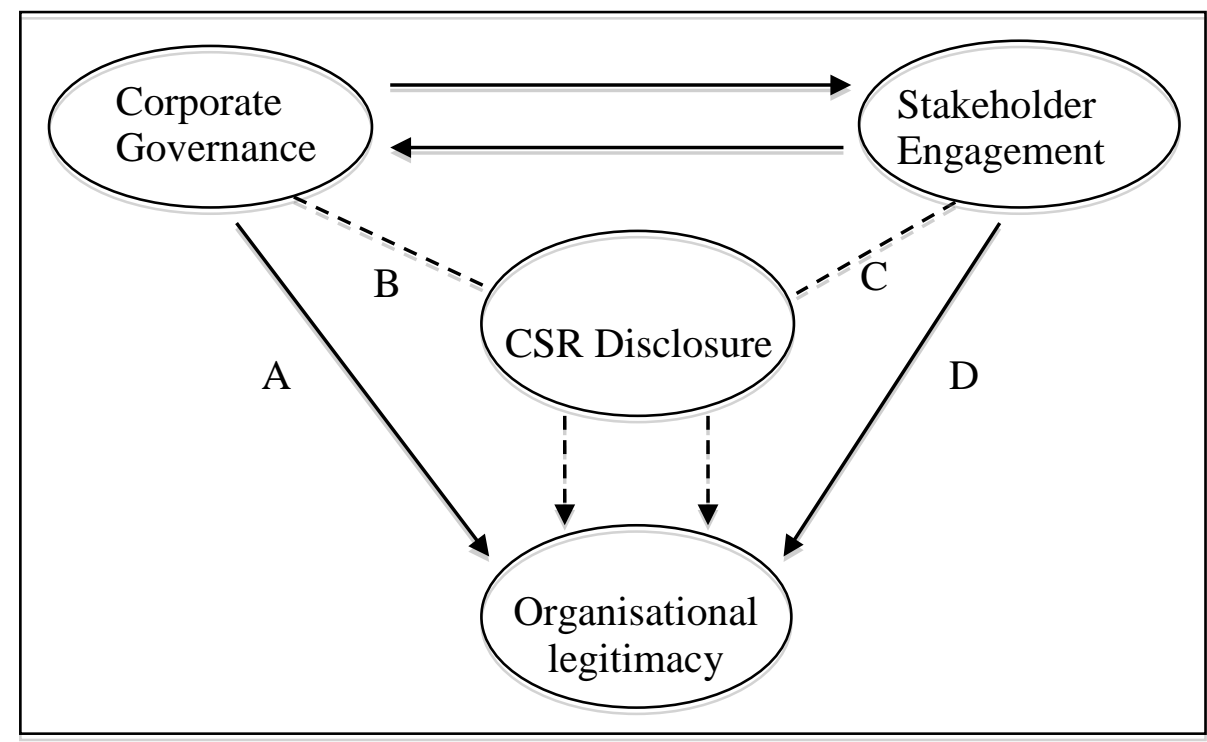

Figure 1 The theoretical framework 


\section{Appendix 1. Disclosure themes and categories.}

I. Environment

(1) Pollution control during typical business operations; capital, operating and research and development expenditures for pollution abatement

(2) Prevention or repair of environmental damage resulting from processing of natural resources, e.g., land reclamation or reforestation; undertaking environmental impact studies to monitor the company's impact on the environment; conducting reviews of performance, emphasising specialist consultants

(3) Receipt of an award for the company's environmental programmes or policies

II. Energy

(4) Disclosure of the company's energy policies; conservation of energy during typical business operations and manufacturing processes

(5) Research aimed at improving product energy efficiency

(6) Receipt of an award for an energy conservation programme

III. Employees

(7) Employee health and safety (reducing or eliminating pollutants, irritants or hazards in the work environment; promoting employee safety and physical or mental health; disclosing accident statistics; receiving a safety award; establishing goals for minority representation in the workforce)

(8) Employee assistance/benefits (providing assistance or guidance to employees who are in the process of retiring or whose work has been made redundant; providing scholarships for employees' children; providing recreational activities/facilities; employee remuneration; disclosing workers compensation arrangements)

(9) Employee morale (providing information on management's relationships with the employees to improve job satisfaction and employee motivation; expressing employee appreciation or recognition)

IV. Marketplace

(10) Product health and safety (health and safety of the product; customer accidents; description of a policy for preserving customer health and safety during the use of products and services; extent to which these policies are visibly stated and applied; monitoring systems and the results of monitoring of these policies)

(11) Costumers and consumers (consumer complaints and related awards; congestion when associated with customer delays but not including additional fuel; specific customer relations (over and beyond 'our duty to the customer'); provision for disabled, aged or otherwise challenged customers; provision for difficult-to-reach customers)

(12) Suppliers, providers (specific creditor relations; policies with regard to creditors; consultation with creditors (frequency, information generated, use of information))

V. $\quad$ Community and involvement

(13) Donations of cash, products or employee services to support established community activities, events, organisations, education and the art 
Authors

(14) Sponsoring educational conferences, seminars or art exhibits, funding scholarship programmes or activities

(15) Supporting the development of local and indigenous communities

VI. Other

(16) CSR objectives and policies (mission statements; ethics; political statements; general references to stakeholders and competitors and to sustainability)

(17) General disclosure of corporate objectives/policies relating to the company's social responsibility to the various segments of society; disclosure of related corporate governance practices. 